\title{
Patterns of Intracellular Calcium Fluctuation in Precursor Cells of the Neocortical Ventricular Zone
}

\author{
David F. Owens and Arnold R. Kriegstein \\ Department of Neurology and The Center for Neurobiology and Behavior, College of Physicians and Surgeons of \\ Columbia University, New York, New York 10032
}

\begin{abstract}
Changes in intracellular free calcium concentration $\left(\left[\mathrm{Ca}^{2+}\right]_{i}\right)$ are known to influence a variety of events in developing neurons. Although spontaneous changes of $\left[\mathrm{Ca}^{2+}\right]_{i}$ have been examined in immature cortical neurons, the calcium dynamics of cortical precursor cells have received less attention. Using an intact cortical mantle and confocal laser microscopy, we examined the spatiotemporal patterns of spontaneous $\left[\mathrm{Ca}^{2+}\right]_{\mathrm{i}}$ fluctuations in neocortical ventricular zone (VZ) cells in situ. The majority of activity consisted of single cells that displayed independent $\left[\mathrm{Ca}^{2+}\right]_{\mathrm{i}}$ fluctuations. These events occurred in cells throughout the depth of the VZ. Immunohistochemical staining confirmed that these events occurred primarily in precursor cells rather than in postmitotic neurons. When imaging near the ventricular surface, synchronous spontaneous $\left[\mathrm{Ca}^{2+}\right]_{i}$ increases were frequently observed in pairs of adjacent cells. Cellular morphology, time-lapse imaging, and nuclear staining
\end{abstract}

demonstrated that this activity occurred in mitotically active cells. A third and infrequently encountered pattern of activity consisted of coordinated spontaneous increases in $\left[\mathrm{Ca}^{2+}\right]_{i}$ in groups of neighboring VZ cells. The morphological characteristics of these cells and immunohistochemical staining suggested that the coordinated events occurred in gap junctioncoupled precursor cells. All three patterns of activity were dependent on the release of $\mathrm{Ca}^{2+}$ from intracellular stores. These results demonstrate distinct patterns of spontaneous $\left[\mathrm{Ca}^{2+}\right]_{\mathrm{i}}$ change in cortical precursor cells and raise the possibility that these dynamics may contribute to the regulation of neurogenesis.

Key words: neurogenesis; intracellular calcium; cell cycle; corticogenesis; ventricular zone; embryonic cortex; calcium imaging
Most neurons of the neocortex arise from precursor cells in the ventricular zone (VZ), a pseudostratified proliferative epithelium that lines the lateral ventricles (Berry and Rogers, 1965; Boulder Committee, 1970). In the rat, neurogenesis proceeds from approximately embryonic day 13 (E13) to E21 (Bayer and Altman, 1995). During this time, precursor cells undergo interkinetic nuclear migration (Seymour and Berry, 1975) in which cells in the DNA synthetic $S$ phase have their nuclei in the upper third of the VZ. When cells pass from $S$ to $G_{2}$, the nuclei migrate toward the VZ surface where mitosis occurs. After mitosis, daughter cells can either remain proliferative and re-enter the cell cycle or become terminally postmitotic and migrate out of the VZ (McConnell, 1995). Glial cells are primarily produced in a second germinal zone, the subventricular zone that is located superficially to the VZ. Glial cell production increases as neurogenesis declines, peaking during the early postnatal period (Bayer and Altman, 1991).

Both intrinsic and extrinsic signals are likely to influence the

Received Jan. 21, 1998; revised March 23, 1998; accepted April 24, 1998.

This work was supported in part by Grant FY95-0879 from the March of Dimes Birth Defects Foundation and by Grant NS 21223 from National Institutes of Health. The confocal facility was established by National Institutes of Health Shared Instrumentation Grant 1S10 RR10506 and is supported by National Institutes of Health Grant 5 P30 CA13696 as part of the Herbert Irving Cancer Center at Columbia University. We thank Theresa Swayne for technical assistance with the confocal microscope, Drs. A. Frankfurter and J. E. Goldman for generously providing the primary antibodies to TuJ1 and vimentin, Eric Kriegstein for help with the illustrations, and Dr. Raphael Yuste, Alexander Flint, Dr. Xiaolin Liu, and Dr. Joseph LoTurco for helpful comments on the manuscript.

Correspondence should be addressed to Dr. Arnold R. Kriegstein, Department of Neurology, College of Physicians and Surgeons of Columbia University, 630 West 168th Street, Box 31, New York, NY 10032.

Copyright $(\odot 1998$ Society for Neuroscience $0270-6474 / 98 / 185374-15 \$ 05.00 / 0$ proliferative potential and eventual fates of precursor cells within the VZ. For example, groups of adjacent precursor cells in different stages of the cell cycle are coupled within the VZ into discrete columnar cell clusters by gap junction channels (LoT urco and Kriegstein, 1991; Bittman et al., 1997). This allows for the spread of electrical and chemical signals to cells within a defined radial compartment within the VZ. In addition, regulation of gap junction coupling seems to influence progression through the cell cycle (Bittman et al., 1997). Ventricular zone cells have also been shown to respond to local environmental signals through peptide and neurotransmitter receptors that in turn can regulate the rate of DNA synthesis in these cells (LoTurco et al., 1995; Lu and DiCicco-Bloom, 1997). Finally, transplantation experiments have demonstrated that the laminar fate of early generated neurons is influenced by environmental cues that commit cells to a specific deep layer fate just before their final mitosis (McConnell and Kaznowski, 1991; Bohner et al., 1997). However, upper layer neurons seem to be fated for superficial layers independent of environmental signals (Frantz and McConnell, 1996).

Modulation of intracellular free calcium concentration $\left(\left[\mathrm{Ca}^{2+}\right]_{\mathrm{i}}\right)$ may be part of the signaling pathway by which both local environmental factors and cell autonomous developmental programs influence corticogenesis. Calcium is a ubiquitous second messenger that has been implicated in the regulation of a variety of events in developing neurons, including differentiation (Spitzer and Gu, 1997), migration (Komuro and Rakic, 1992, 1996), and circuit formation (Yuste et al., 1992; Wong et al., 1995; Feller et al., 1996). Previous studies have demonstrated that spontaneous $\left[\mathrm{Ca}^{2+}\right]_{\mathrm{i}}$ fluctuations occur in immature postmigratory neurons in the postnatal cortex (Yuste et al., 1992, 1995; 
Owens et al., 1996). Less understood are the $\mathrm{Ca}^{2+}$ dynamics of cortical precursor cells in the proliferative zone. The possibility that $\mathrm{Ca}^{2+}$-dependent signaling mechanisms in precursor cells might influence neurogenesis led us to investigate the endogenous $\mathrm{Ca}^{2+}$ dynamics of cells within the intact neocortical VZ.

\section{MATERIALS AND METHODS}

Tissue preparation. Results were obtained from slices and slabs of telencephalic hemispheres obtained from litters of rat pups ranging in age from E15 to E20. Gravid Sprague Dawley rats (Taconic, Germantown, NY) were anesthetized with an intraperitoneal injection of ketamine (50 $\mathrm{mg} / \mathrm{kg}$ ) and xylazine $(10 \mathrm{mg} / \mathrm{kg})$, and embryos were exposed by cesarean section. Embryos were decapitated, and heads were immediately placed in ice-cold artificial CSF (ACSF) (124 mm NaCl, $5 \mathrm{~mm} \mathrm{KCl}, 1.25 \mathrm{~mm}$ $\mathrm{NaH}_{2} \mathrm{PO}_{4}, 1 \mathrm{~mm} \mathrm{MgSO}, 2 \mathrm{~mm} \mathrm{CaCl}, 26 \mathrm{~mm} \mathrm{NaHCO}_{3}$, and $10 \mathrm{~mm}$ glucose) oxygenated with $95 \% \mathrm{O}_{2} / 5 \% \mathrm{CO}_{2}, \mathrm{pH}$ 7.4. Cerebral hemispheres were prepared as slabs of neocortex by trimming off the hippocampus and striatal anlage (see Fig. $1 E$ ). For experiments requiring brain slices, whole embryonic brains were removed and embedded in warm $\left(28-30^{\circ} \mathrm{C}\right) 3-4 \%$ low-melting agarose (Fisher Scientific, Houston, $\mathrm{TX})$ in ACSF, were hardened on ice, and were sliced into coronal sections $(300-400 \mu \mathrm{m})$ with a vibratome.

Calcium imaging. Neocortical slabs and slices were loaded in the dark with the $\mathrm{Ca}^{2+}$ indicator dye fluo-3 by immersion for at least $30 \mathrm{~min}$ in ACSF containing fluo-3 AM $(10 \mu \mathrm{M})$ followed by a brief ACSF wash. Tissue was placed in a imaging chamber continuously perfused with oxygenated ACSF, on the stage of a Zeiss Axiovert microscope (40×; numerical aperture, 0.75 objective). Illumination was provided with either a Bio-Rad MRC-600 argon laser scanning confocal attachment or a Zeiss argon crypton laser scanning confocal attachment. Excitation was at $488 \mathrm{~nm}$, and emissions were collected using a $515 \mathrm{~nm}$ long-pass emission filter. Neutral density filters were used to filter the argon laser light to $1 \%$ to minimize photobleaching. Generally, one image was acquired every $2.88-7 \mathrm{sec}$, with each image consisting of an average of two to four frames. In some experiments, we used faster (up to one image every $0.2 \mathrm{sec}$ without frame averaging) or slower (down to one image every $11 \mathrm{sec}$ to average up to 16 frames per image) image acquisition. Images were acquired on an IBM-compatible computer running either Comos (Bio-Rad, Hercules, CA) or LSM (Zeiss) acquisition software. Fluorescence micrographs were digitized, and relative changes in $\left[\mathrm{Ca}^{2+}\right]_{\mathrm{i}}$ were measured in selected cells using the public domain National Institutes of Health Image program (written by Wayne Rasband at the National Institutes of Health) on a Macintosh 7200 computer. Data are expressed as a change in fluorescence over baseline fluorescence $(\Delta F / F)$. Depending on the number of images acquired per experimental trial, the baseline $\mathrm{F}$ was defined as the image with the minimum level of fluorescence or as an average of the five minimum images for each trial. Intracellular $\mathrm{Ca}^{2+}$ transient durations were estimated by measuring the time from the initial deviation from baseline to return (Ferrari et al., 1996). Average values are expressed as mean \pm SEM. Statistical analysis was performed with a two-tailed Student's $t$ test, and $p$ values of $\leq 0.05$ were considered statistically significant. Unless otherwise stated, all experiments were performed at room temperature (RT; $\left.21-25^{\circ} \mathrm{C}\right)$.

$\mathrm{Ca}^{2+}$ imaging and subsequent cell identification. In some experiments, tissue was processed for immunohistochemistry after $\mathrm{Ca}^{2+}$ imaging. In these experiments, maps were made of anatomical landmarks, and the orientation of tissue in the imaging chamber was recorded so that the same areas could be visualized subsequently for neuronal-specific immunoreactivity. After we performed live $\mathrm{Ca}^{2+}$ imaging, the tissue was fixed in $4 \%$ paraformaldehyde and stored overnight at $4^{\circ} \mathrm{C}$. Tissue was washed in PBS and then permeabilized and blocked in PBS with $0.5 \%$ Triton $\mathrm{X}-100$ and $10 \%$ normal goat serum (NGS) for $1 \mathrm{hr}$ at RT. Tissue was then incubated overnight at $4^{\circ} \mathrm{C}$ with anti-TuJ1 primary antibody $(1: 500$ dilution; generously provided by Dr. A. Frankfurter, University of Virginia) in PBS with $0.1 \%$ Triton X-100 and $3 \%$ NGS. Tissue was washed and then incubated for $1 \mathrm{hr}$ at $\mathrm{RT}$ with rhodamine-conjugated antimouse secondary antibody (1:200 dilution; ICN Biomedicals, Cleveland, $\mathrm{OH}$ ) in PBS with $0.1 \%$ Triton X-100 and 3\% NGS. After being washed, the tissue was viewed on the confocal microscope as described above; however, excitation was at $568 \mathrm{~nm}$, and emissions were collected using a $590 \mathrm{~nm}$ long-pass emission filter. Once the TuJ1-stained tissue was oriented correctly in the imaging chamber, a $\mathrm{Z}$ series of up to 60 serial $1-2 \mu \mathrm{m}$ sections was taken through the tissue beginning at the most superficial tissue plane. This was done to facilitate recovery of the same optical section that had been viewed during $\mathrm{Ca}^{2+}$ imaging, even if tissue distortion had occurred during processing. Z-series sections were then digitally superimposed for each tissue field viewed during the $\mathrm{Ca}^{2+}$ imaging experiments with the aid of National Institutes of Health Image and Freehand (Macromedia) programs running on a Macintosh 7200 computer. Cells that were active during the $\mathrm{Ca}^{2+}$ imaging period were then checked for corresponding TuJ1 immunoreactivity. In many cases we were able to positively identify individual cells in the same areas using these methods.

In some experiments, $\mathrm{Ca}^{2+}$ imaging was followed by incubation of cortical slabs in oxygenated ACSF containing $5 \mu \mathrm{M}$ syto- 11 (Chenn and McConnell, 1995) for $5 \mathrm{~min}$. Tissue was then rinsed, transferred to the imaging chamber, and reimaged with the laser confocal microscope as described above.

Filling of VZ cells with the cell-impermeant potassium salt of fluo-3. We used the "blind" whole-cell patch-clamp recording method (Blanton et al., 1989) to fill gap junction-coupled clusters of VZ cells (LoTurco and Kriegstein, 1991). Briefly, 8-12 M $\Omega$ electrodes were filled with a recording solution containing $130 \mathrm{~mm} \mathrm{KCl}, 5 \mathrm{~mm} \mathrm{NaCl}, 1 \mathrm{mM} \mathrm{MgCl}_{2}, 10 \mathrm{~mm}$ HEPES, and the impermeant $\mathrm{K}^{+}$salt of fluo-3 (100 $\mu \mathrm{M}$; Molecular Probes, Eugene, OR). Fluo-3 is a molecule small enough to pass through gap junction channels (960 molecular weight). We identified cells as being members of clusters because of their low membrane resistances (LoTurco and Kriegstein, 1991). After dye filling, the injected slab was transferred from the electrophysiological recording chamber to the imaging chamber and visualized with the laser confocal microscope as described above.

Pharmacological agents and drug application. Bicuculline methiodide (BMI), lanthanum $\left(\mathrm{La}^{3+}\right)$, EGTA, and tetrodotoxin (TTX) were obtained from Sigma (St. Louis, MO); 6-cyano-7-nitroquinoxaline-2,3dione (CNQX), 2-amino-5-phosphonopentanoic acid (AP-5), caffeine, and thapsigargin were obtained from Research Biochemicals (Natick, MA); and fluo-3 AM and syto-11 were obtained from Molecular Probes. All drugs were bath applied. Drugs were either added directly to solutions or kept as concentrated stock solutions at $-20^{\circ} \mathrm{C}$ (BMI, CNQX, AP-5, syto-11, and thapsigargin) or $4^{\circ} \mathrm{C}\left(\mathrm{La}^{3+}\right.$ and TTX) and diluted to the desired concentration on the day of the experiment. Fluo-3 AM solution was made on the day of the experiment from aliquots stored at $-20^{\circ} \mathrm{C}$.

Immunohistochemistry. Embryos were transcardially perfused with $4 \%$ paraformaldehyde; heads were removed, post-fixed in $4 \%$ paraformaldehyde, and stored overnight at $4^{\circ} \mathrm{C}$. Heads were washed in PBS and placed in $30 \%$ sucrose for $24 \mathrm{hr}$. Whole brains were removed from the heads, placed in embedding medium (Tissue-tek, OCT, Sakura Fine Tek, Torrance, CA), and frozen. Frozen coronal sections (15-20 $\mu \mathrm{m})$ were cut on a cryostat and air dried. Sections were washed in PBS and then permeabilized and blocked in PBS with $0.5 \%$ Triton X-100 and 10\% NGS for $1 \mathrm{hr}$ at RT. Next, tissue was incubated for $2 \mathrm{hr}$ at RT with primary antibody [anti-TuJ1, 1:500 dilution; anti-vimentin, 1:6 dilution (generously provided by Dr. J. E. Goldman, Columbia University)] in PBS with $0.1 \%$ Triton X-100 and 3\% NGS. Tissue was washed and then incubated for $1 \mathrm{hr}$ at RT with rhodamine-conjugated anti-mouse secondary antibody (1:200 dilution; ICN Pharmaceuticals) in PBS with $0.1 \%$ Triton $\mathrm{X}-100$ and $3 \%$ NGS. After being washed, the tissue was viewed with laser confocal microscopy as described above or by epifluorescence using a Zeiss Axioscope.

5-Bromo-2'-deoxyuridine labeling. Embryonic brains were isolated as described above and placed in $20 \mu \mathrm{M} 5$-bromo-2'-deoxyuridine (BrDU) in oxygenated $\mathrm{ACSF}$ at $37^{\circ} \mathrm{C}$ for $1,4,6$, and $8 \mathrm{hr}$. These times were selected to label cells primarily in $S ; S$ and $G_{2} ; S, G_{2}$, and $M$; and $S, G_{2}$, $M$, and $G_{1}$ phases of the cell cycle, respectively (Takahashi et al., 1995). Tissue was fixed overnight in $4 \%$ paraformaldehyde at $4^{\circ} \mathrm{C}$ and then washed in PBS. Frozen coronal sections were made as described above. Sections were rinsed in PBS and then incubated in $2 \mathrm{~N} \mathrm{HCl}$ for 30 min at $37^{\circ} \mathrm{C}$. After being washed, sections were incubated in $0.1 \mathrm{M}$ borax for 10 min at RT, washed, permeabilized, and blocked in PBS with $0.5 \%$ Triton X-100 and $10 \%$ NGS for $1 \mathrm{hr}$ at RT. Sections were then incubated in anti-BrDU primary antibody (1:200 dilution; Vector Laboratories, Burlingame, CA) in $0.1 \%$ Triton X-100 and 3\% NGS in PBS for $2 \mathrm{hr}$ at $\mathrm{RT}$, washed in PBS, and then incubated in Cy3-conjugated goat antimouse secondary antibody (1:200 dilution; Jackson ImmunoResearch, West Grove, PA) in $0.1 \%$ Triton X-100 and 3\% NGS in PBS for $1 \mathrm{hr}$ at RT. After being washed, the tissue was visualized with laser confocal microscopy as described above or by epifluorescence. 
A

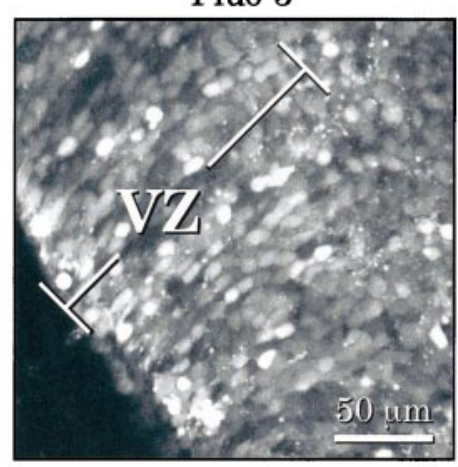

C

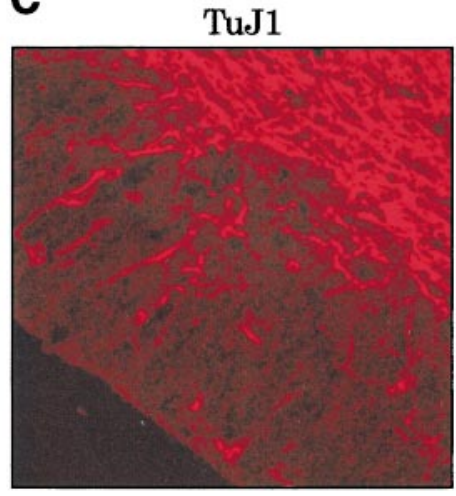

B

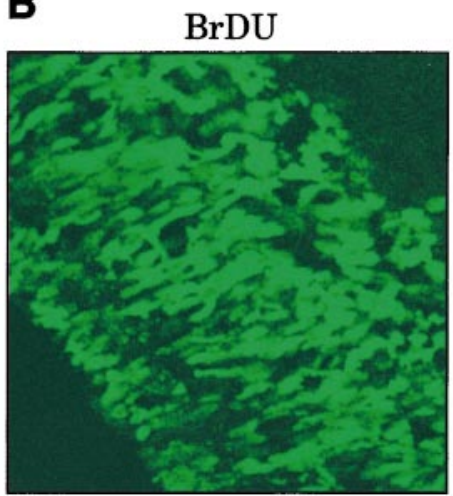

D

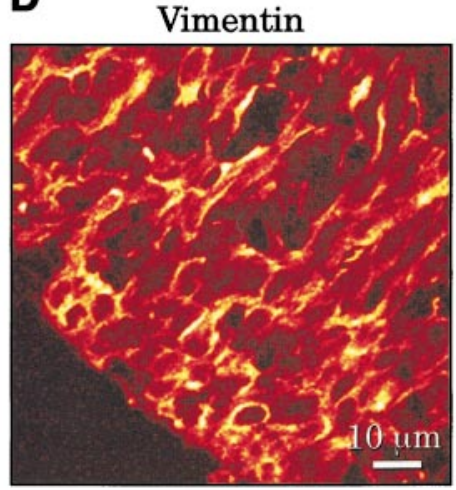

E

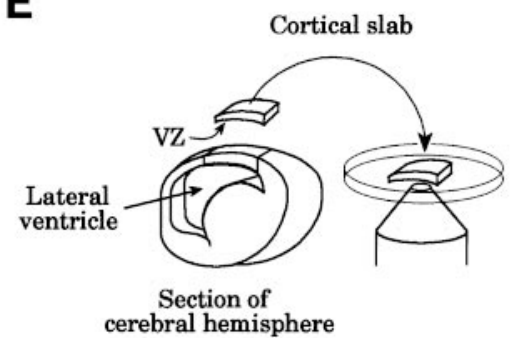

F

Fluo-3

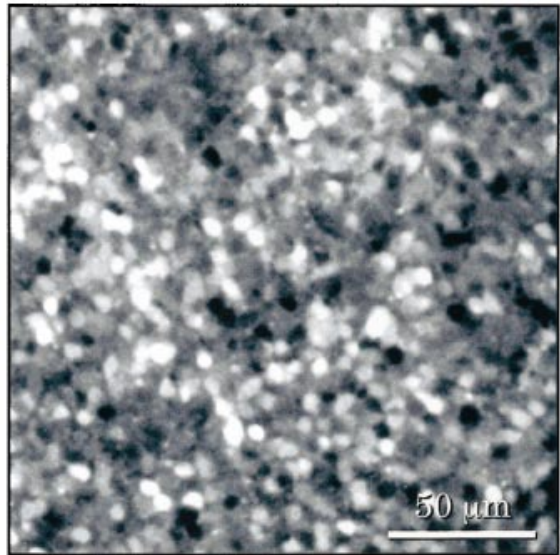

Figure 1. Most imaged cells in the $V Z$ are proliferative neocortical precursor cells. $A$, Single optical section of a fluo-3 AM-loaded coronal E16 brain slice. Large numbers of cells load with the $\mathrm{Ca}^{2+}$ indicator. $B$, Single optical section of an E16 coronal brain slice pulsed for $6 \mathrm{hr}$ with BrDU to label cells in $\mathrm{S}, \mathrm{G}_{2}$, and $\mathrm{M}$ phases of the cell cycle. $C$, Single optical section of a coronal E17 brain slice stained for the neuronal marker TuJ1. Scale bar: $A-C$, $50 \mu \mathrm{m}$. $D$, Single optical section of an E17 brain slice stained for the radial glia marker vimentin. E, Schematic representation of the experimental preparation. A section of an intact neocortical hemisphere (cortical slab) is removed, loaded with fluo-3 AM, and placed ventricular surface down in an imaging chamber attached to the stage of an inverted confocal microscope. $F$, Representative view of the $V Z$ from an E17 cortical slab.

\section{RESULTS}

\section{Distinct patterns of spontaneous $\left[\mathrm{Ca}^{2+}\right]_{\mathrm{i}}$ fluctuation in VZ cells}

During cortical neurogenesis, the VZ contains neural and glial precursor cells, radial glia, and postmitotic neurons. Because fluo-3 appears to label most cells in the in vitro embryonic cortex, we performed immunohistochemistry using specific markers to help identify imaged cells as proliferative cells, radial glia, or postmitotic neurons. Incubation in fluo-3 AM leads to loading of a majority of the cells in the VZ (Fig. $1 A$ ). Proliferating cells in $\mathrm{S}, \mathrm{G}_{2}$, and $\mathrm{M}$ phases of the cell cycle were labeled by exposing the cortex to BrDU for $6 \mathrm{hr}$ in vitro (Fig. $1 B$ ). The majority of the cells in the $\mathrm{VZ}$ are positively stained for this marker. In contrast, Figure $1 C$ demonstrates that very few VZ cells were positively stained by the TuJ1 antibody, a marker of postmitotic neurons (Lee et al., 1990). Figure $1 D$ shows vimentin staining at E17, which labels radial glia (Rakic, 1995). Vimentin-stained fibers can be seen coursing around negatively labeled cell bodies within the VZ. These experiments indicate that at E16 and E17, the majority of cells imaged in the VZ are proliferating precursor cells in different phases of the cell cycle.

To visualize the spatiotemporal pattern of activity in neocortical VZ cells in situ, we used an experimental preparation that kept the cortical mantle intact. The embryonic cerebral cortex was removed, and after being loaded with fluo-3 AM, the intact cortical mantle (cortical slab) was placed ventricular surface down on the stage of a confocal microscope (Fig. $1 E$ ). Cells within the $\mathrm{VZ}$ were then visualized and imaged (Fig. $1 F$ ). This preparation differs from conventional brain slices because it enables observations of spontaneously active VZ cells within a large sheet of intact embryonic cortex. Using the slab preparation, we were able to image cells in an optical section parallel to the ventricular surface to depths up to $40 \mu \mathrm{m}$. We observed three distinct patterns of spontaneous $\left[\mathrm{Ca}^{2+}\right]_{\mathrm{i}}$ fluctuations in VZ cells; individual cells undergoing independent $\left[\mathrm{Ca}^{2+}\right]_{\mathrm{i}}$ fluctuations, pairs of adjacent cells undergoing synchronous $\left[\mathrm{Ca}^{2+}\right]_{i}$ fluctuations, and clusters of neighboring cells undergoing coordinated $\left[\mathrm{Ca}^{2+}\right]_{\mathrm{i}}$ fluctuations. In each case the $\left[\mathrm{Ca}^{2+}\right]_{\mathrm{i}}$ increase was localized to the cell soma.

\section{Single-cell behavior}

The most common pattern of $\left[\mathrm{Ca}^{2+}\right]_{\mathrm{i}}$ fluctuation consisted of individual cells displaying intermittent $\left[\mathrm{Ca}^{2+}\right]_{\mathrm{i}}$ transients (Fig. 2). Spontaneously active single cells were present at all ages examined (E15-E20). These cells were distributed throughout the slab and could be in close proximity to one another but were generally not in contact. In Figure $2 A_{1}$, a representative microscopic field from an E17 slab is shown with all of the cells active during the $20 \mathrm{~min}$ imaging period circled. Figure $2 A_{2}$ shows a single cell before, during, and after an event. The temporal patterns of 
A 1

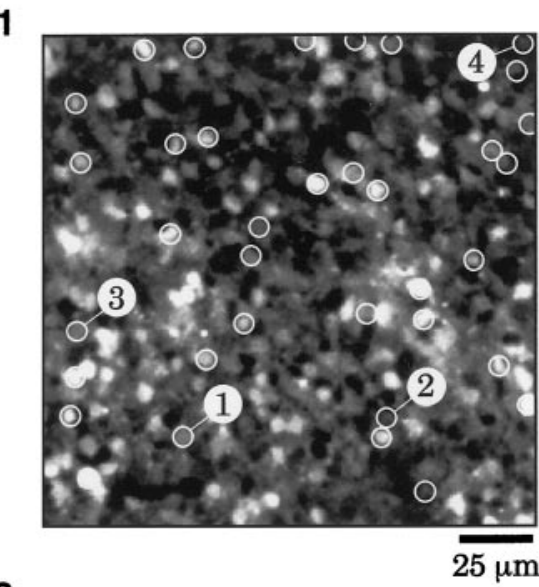

2

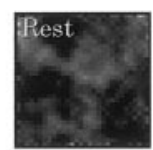

C
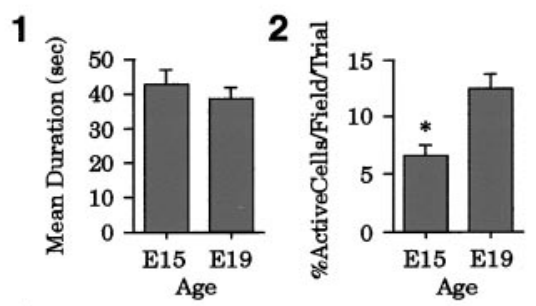

3

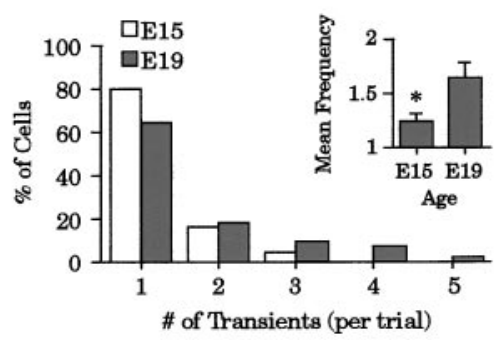

3

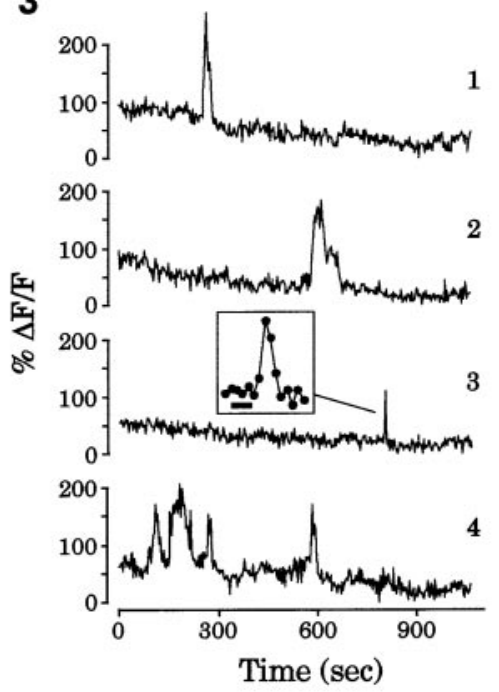

\section{D}

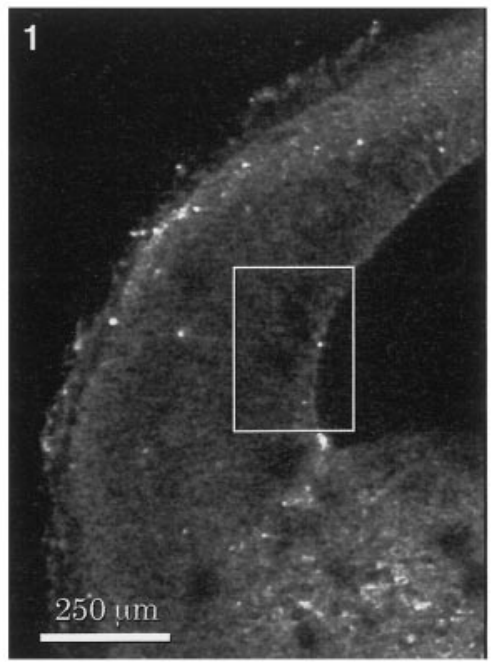

2
B 1
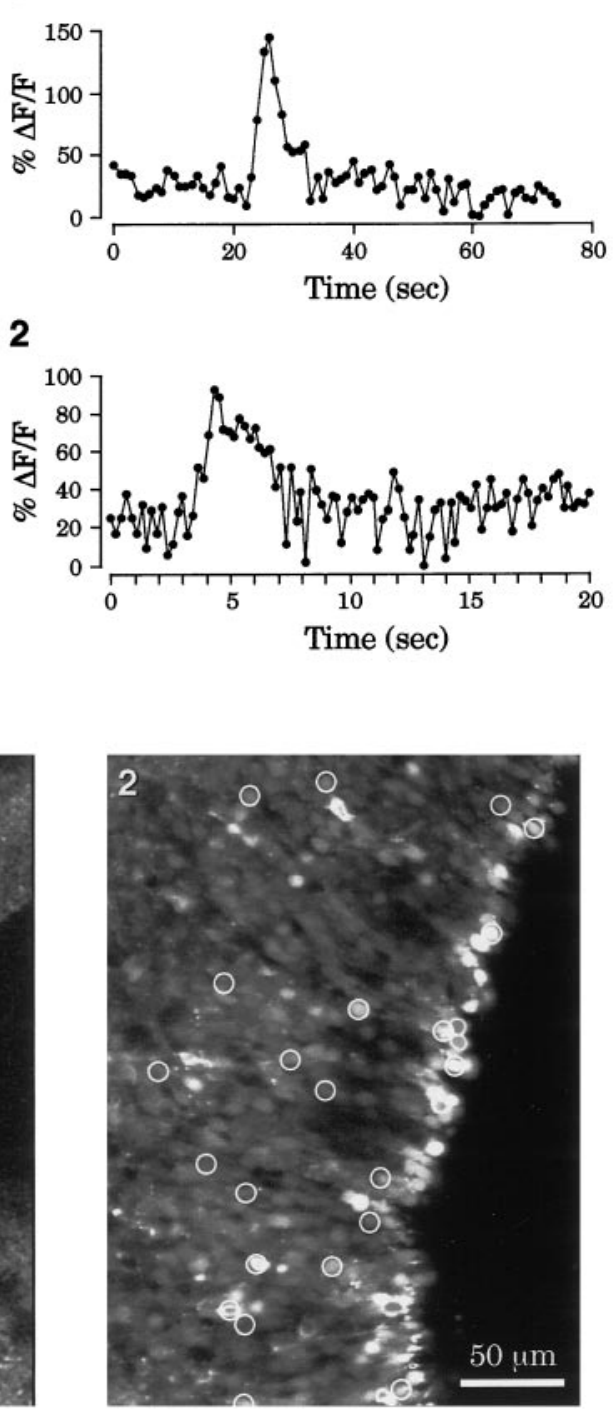

Figure 2. Individual cells display intermittent $\left[\mathrm{Ca}^{2+}\right]_{\mathrm{i}}$ transients. $A_{1}$, A microscopic field from an E17 slab imaged in an optical plane $\sim 20 \mu \mathrm{m}$ from the ventricular surface. Circles indicate cells that were active over a continuous imaging period of $\sim 20 \mathrm{~min}$. $A_{2}$, A cell before (Rest), during (Peak), and after (Return) a spontaneous $\left[\mathrm{Ca}^{2+}\right]_{\mathrm{i}}$ increase. $A_{3}$, Activity graphs of the numbered cells $(1-4)$ shown in $A_{1}$. Calcium transients ranged from relatively fast events (cell 3) to slow events (cell 2). The inset for cell 3 is an expanded plot of the event with measured values indicated by filled circles. Scale bar in inset, $10 \mathrm{sec}$. A minority of cells showed multiple transients (e.g., cell 4 ) over the imaging period. $B$, Faster sampling showing that the single-cell events generally occurred over many seconds. $B_{1}$, A cell sampled every second. $B_{2}$, A cell sampled every $0.215 \mathrm{sec}$. $C$, A developmental increase in the number and frequency of single-cell events but no change in duration. $C_{1}$, The similar mean durations of $\left[\mathrm{Ca}^{2+}\right]_{\mathrm{i}}$ transients at E15 and E19. $C_{2}$, A significant increase in the percentage of active cells/field/trial at E19. Asterisk indicates a significant difference. $C_{3}$, At E19, a larger percentage of cells with multiple transients than at E15. The inset displays the mean frequency per trial of all cells analyzed at the two ages. There was an increase in mean frequency at E19. Asterisk indicates a significant difference. $D$, Spontaneous $\left[\mathrm{Ca}^{2+}\right]_{\mathrm{i}}$ fluctuations observed in cells throughout the VZ. $D_{1}$, A fluo-3-loaded coronal brain slice at E16 with the area imaged indicated by a box. $D_{2}$, Higher magnification image with active cells indicated by circles.

$\left[\mathrm{Ca}^{2+}\right]_{\mathrm{i}}$ increase for four of the cells are shown in Figure $2 A_{3}$ and illustrate the range of transient durations encountered $(32,95$, and $14 \mathrm{sec}$ for cells $1-3$, respectively) as well as the occurrence of recurrent transients in the same cell (cell 4). The mean duration for events recorded from a sample of 63 cells at E17 was $37.1 \pm$ $4.3 \mathrm{sec}$ (range, $11.5-121 \mathrm{sec}$ ), and the majority of cells $(82.5 \%)$ demonstrated a single transient in the course of $20 \mathrm{~min}$. Furthermore, these events seemed to occur randomly throughout each field with no obvious intercellular synchrony. Similar behavior was observed in experiments conducted at $32-34^{\circ} \mathrm{C}$. In a sample of 29 active cells at $32-34^{\circ} \mathrm{C}$, the average transient duration was
$33 \pm 3.6 \mathrm{sec}$, and $81 \%$ of the cells displayed a single transient over the imaging period.

Considering the sampling rate of $\sim 3 \mathrm{sec} /$ image used in these experiments, we determined that the fastest event that could be resolved was $\sim 6 \mathrm{sec}$. To investigate whether we were missing faster events, we performed several experiments in which images were acquired at faster sampling rates. Figure $2 B_{1}$ shows a transient from a cell sampled every second; the duration of the event was $11 \mathrm{sec}$, and the interval from transient onset to peak spanned several images, indicating that the time-to-peak of the transient is in the range of seconds. In 15 active cells sampled at 0.2-1 
sec/image, we captured the entire transient and found that the mean duration was $11.1 \pm 1.6 \mathrm{sec}$ and that the fastest event was $\sim 4-5 \mathrm{sec}$ (Fig. $2 B_{2}$, sampled at $0.215 \mathrm{sec} / \mathrm{image}$ ). Collectively these results suggest that single-cell transients have relatively slow onsets, last many seconds, and repeat at low frequency. Also, we would be likely to detect most, if not all, of these events by sampling every 5-10 seconds.

\section{Developmental change in single-cell behavior}

To investigate developmental differences, we imaged multiple areas from slabs at E15 and E19, ages that correspond to early and late neurogenesis, respectively (Bayer and Altman, 1991). In these experiments, we sampled tissue fields every $7 \mathrm{sec}$ over a period of $3.5 \mathrm{~min}$; each of these samples was considered one trial. Comparing multiple cells at the two different ages demonstrated that the transient durations of single-cell events did not change with age (Fig. $2 C_{1}$ ). The mean duration at E15 was $42.5 \pm 4.4 \mathrm{sec}$ $(n=48)$, and the mean duration at E19 was $38.6 \pm 3.0 \mathrm{sec}(n=$ 78); these values were not significantly different.

Although the single-cell transient durations were similar between the two ages analyzed, there was a tendency for cells from older embryos to be more active in terms of the number of cells demonstrating $\left[\mathrm{Ca}^{2+}\right]_{\mathrm{i}}$ fluctuations and of the frequency of $\left[\mathrm{Ca}^{2+}\right]_{\mathrm{i}}$ fluctuations in individual cells. To quantify these trends, we counted the number of active cells for a defined area and the number of transients per cell during a single imaging trial. Figure $2 C_{2}$ shows the percentage of active cells in multiple fields from slabs at E15 and E19. The mean percentage of active cells per trial at E15 was $6.64 \pm 0.92 \%$ ( $n=6$ fields from three slabs), whereas at E19 it was $12.5 \pm 1.2 \%$ ( $n=5$ fields from two slabs). This indicates an increase of $53.2 \%$ in active cells with age $(p<$ $0.004)$. Figure $2 C_{3}$ shows that at E15 $20 \%$ of the cells showed more than one transient, whereas at E19 this value increased to $\sim 35 \%$. The inset of Figure $2 C_{3}$ displays the mean frequency of all cells analyzed at the two ages. At E15 there was a mean frequency of $1.24 \pm 0.1$ transients per imaging trial $(n=50)$, and at E19 there was a mean frequency of $1.64 \pm 0.1$ transients per imaging trial $(n=56)$. The difference between these values was statistically significant $(p<0.01)$.

\section{Spontaneous $\left[\mathrm{Ca}^{2+}\right]_{\mathrm{i}}$ fluctuations occur throughout the VZ}

To examine the spatial distribution of VZ cells demonstrating spontaneous $\left[\mathrm{Ca}^{2+}\right]_{\mathrm{i}}$ fluctuations, we performed experiments in brain slices. In multiple experiments, we observed spontaneous $\left[\mathrm{Ca}^{2+}\right]_{\mathrm{i}}$ fluctuations in cells that spanned the entire depth of the VZ. The kinetics of the $\left[\mathrm{Ca}^{2+}\right]_{\mathrm{i}}$ transients was similar to that observed in the cortical slab preparation. Figure $2 D_{1}$ shows an example of a coronal brain slice from an E16 embryo with the area imaged indicated by a box. Figure $2 \mathrm{D}_{2}$ shows the imaged area at higher magnification and the spontaneously active cells outlined (circles). In the 26 active cells seen over $\sim 15 \mathrm{~min}$ of imaging in this example, the mean transient duration was $36.8 \pm$ $5.3 \mathrm{sec}$, and $79 \%$ of the cells had a single transient during the imaging period. These values from cortical slices are similar to those obtained from cortical slabs and indicate that single-cell behavior is similar in both tissue preparations.

\section{Mechanisms of spontaneous $\left[\mathrm{Ca}^{2+}\right]_{\mathrm{i}}$ fluctuations in VZ cells}

Cells within the VZ express functional amino acid transmitter receptors that, when activated, lead to membrane depolarization and increases in $\left[\mathrm{Ca}^{2+}\right]_{\mathrm{i}}$ (LoTurco et al., 1995). There are several neuronal populations in the developing cortex that could be sources of endogenous transmitter release, including neurons in the intermediate zone (IZ), subplate, and cortical plate (CP) (Kim et al., 1991; McConnell et al., 1994; Behar et al., 1996; Anderson et al., 1997). We therefore examined whether spontaneous $\left[\mathrm{Ca}^{2+}\right]_{\mathrm{i}}$ fluctuations in $\mathrm{VZ}$ cells were mediated by action potential-dependent transmitter release. Images of cortical slabs (E19) were taken to establish a basal level of spontaneous activity. Slabs were subsequently preincubated in a solution containing TTX $(2 \mu \mathrm{M})$, to block sodium-dependent action potentials, for a minimum of $3 \mathrm{~min}$ and then reimaged in the continued presence of TTX. Similar levels of activity were present before and after immersion in TTX (data not shown). A second series of experiments was performed using brain slices to circumvent the possibility that the intact ventricular surface provided a barrier to drug access. Cells near the ventricular surface of the slice were monitored, and activity was still present in the TTX-containing solution (data not shown). We also found that activity persisted in solutions that contained, in addition to TTX, the nonspecific voltage-gated $\mathrm{Ca}^{2+}$ channel (VGCC) blocker lanthanum $(50 \mu \mathrm{M})$, the $\mathrm{GABA}_{\mathrm{A}}$ receptor blocker BMI $(20 \mu \mathrm{M})$, the non-NMDA glutamate receptor blocker CNQX $(20 \mu \mathrm{M})$, and the NMDA receptor blocker AP-5 $(100 \mu \mathrm{M})$. Figure $3 A$ depicts the levels of activity for three cells in an E19 slice before and after the addition of the inhibitors. From these data, we conclude that neural activity, VGCC activation, and amino acid neurotransmitter receptor activation are not required for the spontaneous $\left[\mathrm{Ca}^{2+}\right]_{\mathrm{i}}$ increases in individual $\mathrm{VZ}$ cells.

To test whether the $\left[\mathrm{Ca}^{2+}\right]_{\mathrm{i}}$ increases were dependent on extracellular $\mathrm{Ca}^{2+}$, we performed experiments in $\mathrm{Ca}^{2+}$. containing and $\mathrm{Ca}^{2+}$-free $\left(0 \mathrm{Ca}^{2+}\right.$ and $2 \mathrm{~mm}$ EGTA) ACSF solutions. Embryonic cortical slabs were preincubated in normal $\left(2 \mathrm{mM} \mathrm{Ca}^{2+}\right)$ or $\mathrm{Ca}^{2+}$-free ACSF for at least $30 \mathrm{~min}$ before imaging, and comparisons were made of the activity in both conditions. In some experiments, slabs and slices were imaged first in normal ACSF, followed by imaging of the same area 20-30 min after exchange of normal ACSF for $\mathrm{Ca}^{2+}$-free ACSF. Results from several experiments showed that in all cases similar levels of activity were present in $\mathrm{VZ}$ cells in both $\mathrm{Ca}^{2+}$ and $\mathrm{Ca}^{2+}$-free conditions. Figure $3 B$ shows graphs of $\left[\mathrm{Ca}^{2+}\right]_{\mathrm{i}}$ changes from three cells in an E16 slice recorded in both normal and $\mathrm{Ca}^{2+}$-free ACSF bath solutions. There were no obvious differences in the behavior of the $\left[\mathrm{Ca}^{2+}\right]_{i}$ transients under the two imaging conditions. In experiments using E19 slabs, we found the mean transient duration was $45.4 \pm 3.6 \mathrm{sec}(n=80)$ in $\mathrm{Ca}^{2+}$-free conditions, and the average frequency was $1.60 \pm 0.1$ transients per imaging trial $(n=65)$. Comparison of these parameters with those obtained at E19 under conditions of standard extracellular $\mathrm{Ca}^{2+}(2 \mathrm{~mm})$ showed no significant differences (mean duration at E19 was $38.6 \pm 3.0 \mathrm{sec}$; mean frequency was $1.64 \pm 0.1$ transients per imaging trial).

These results suggest that the majority of spontaneous $\left[\mathrm{Ca}^{2+}\right]_{i}$ fluctuations in $\mathrm{VZ}$ cells may be mediated by $\mathrm{Ca}^{2+}$ released from intracellular stores. To test this possibility directly, we examined cortical slabs before and after incubation in an ACSF solution containing thapsigargin $(5 \mu \mathrm{M})$, a $\mathrm{Ca}^{2+}$-ATPase inhibitor that depletes intracellular $\mathrm{Ca}^{2+}$ stores (Thastrup et al., 1990). Fluo3-loaded cortical slabs were first imaged to establish baseline levels of activity. The slabs were subsequently incubated in thapsigargin for at least $15 \mathrm{~min}$ and then reimaged in the continued presence of thapsigargin. After treatment with thapsigargin, spontaneous activity in VZ cells was almost completely abol- 

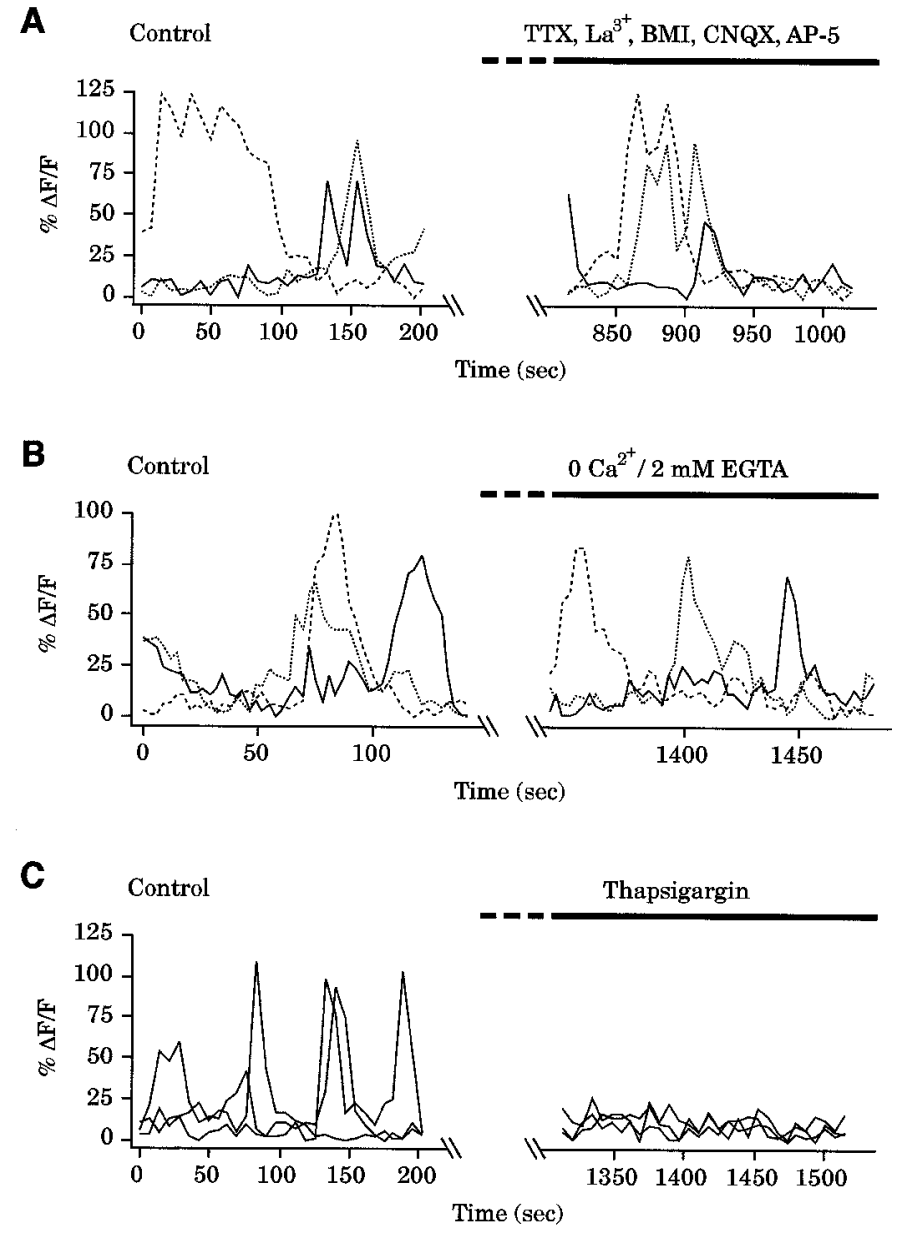

Figure 3. Mechanisms of spontaneous $\left[\mathrm{Ca}^{2+}\right]_{\mathrm{i}}$ fluctuation in $\mathrm{VZ}$ cells. $A$, Three cells (solid, dashed, and dotted lines) near the ventricular surface of a coronal slice at E19. Activity persisted in the presence (solid horizontal bar) of TTX $(2 \mu \mathrm{M}), \mathrm{La}^{3+}(50 \mu \mathrm{M})$, BMI $(20 \mu \mathrm{M})$, CNQX $(20 \mu \mathrm{M})$, and AP-5 $(100 \mu \mathrm{M})$. $B$, Three cells at E16 recorded in $\mathrm{Ca}^{2+}(2 \mathrm{mM})$ ACSF (control) and after $\sim 20 \mathrm{~min}$ of perfusion with $\mathrm{Ca}^{2+}$-free/2 mM EGTA ACSF. There were no obvious differences in the behavior of the $\left[\mathrm{Ca}^{2+}\right]_{\mathrm{i}}$ transients. $C$, Representative examples of activity in three cells (solid lines) under control conditions and three cells after exposure to thapsigargin $(5 \mu \mathrm{M})$. Spontaneous activity in VZ cells was abolished after exposure to thapsigargin.

ished; only a few cells were seen to produce spontaneous $\left[\mathrm{Ca}^{2+}\right]_{\mathrm{i}}$ fluctuations in multiple imaging trials from two separate slabs (Fig. 3C). This effect was not caused by cell injury or death because $\mathrm{VZ}$ cells still produce $\left[\mathrm{Ca}^{2+}\right]_{\mathrm{i}}$ increases in the presence of thapsigargin when exposed to agents that depolarize the cells (data not shown).

Most single-cell transients occur in non-neuronal cells

Although immunohistochemical analysis suggests that the majority of imaged cells are precursor cells (see Fig. 1), similar spontaneous $\left[\mathrm{Ca}^{2+}\right]_{\mathrm{i}}$ fluctuations have been observed in postmitotic neurons, including migrating cerebellar granule cells (Komuro and Rakic, 1996), immature spinal cord neurons (Gu et al., 1994; $\mathrm{Gu}$ and Spitzer, 1995), and neonatal cortical neurons (Yuste et al., 1992; Owens et al., 1996). We therefore combined $\mathrm{Ca}^{2+}$ imaging and $\mathrm{TuJ} 1$ labeling to confirm the identity of spontaneously active VZ cells. The neuronal marker TuJ1 has been used previously to identify immature neurons in the neocortical $\mathrm{VZ}$
(Menezes and Luskin, 1994; O'Rourke et al., 1997). We first imaged both slabs and slices of embryonic cortex to observe cells that displayed spontaneous $\left[\mathrm{Ca}^{2+}\right]_{\mathrm{i}}$ fluctuations. The tissue was subsequently fixed and stained for TuJ1 immunoreactivity, and the same regions were reimaged (see Materials and Methods). Consistent with results reported in the mouse (Menezes and Luskin, 1994), we found little or no TuJ1 immunoreactivity in the VZ on E15 (approximately E13 in the mouse); however, in these same slices, many cells throughout the depth of the $\mathrm{VZ}$ had spontaneous $\left[\mathrm{Ca}^{2+}\right]_{\mathrm{i}}$ fluctuations (Fig. $4 A$ ). Figure $4 A$ shows a coronal slice from an E15 embryo that was imaged for spontaneous $\left[\mathrm{Ca}^{2+}\right]_{\mathrm{i}}$ increases and then for TuJ1 immunoreactivity. The cells outlined with circles were active during $\mathrm{Ca}^{2+}$ imaging (Fig. $4 A$, left ), and the corresponding cell locations are indicated in the TuJ1-stained section (Fig. $4 A$, right). In only one case was a clear $\mathrm{TuJ} 1$-positive cell body present where an active cell was seen during $\mathrm{Ca}^{2+}$ imaging (Fig. 4A, arrow on right). Furthermore, there were no TuJ1-stained cell bodies near the VZ surface where the active cells in tissue slab experiments were seen. These results suggest that the majority of spontaneous single-cell activity is mediated by precursor cells that do not express the $\mathrm{TuJ} 1$ antigen.

As neurogenesis proceeds, there is an increase in the number of postmitotic neurons that are $\mathrm{TuJ} 1$-positive in the VZ (Menezes and Luskin, 1994). Therefore, it is possible that at later developmental periods (e.g., E19) the VZ contains both neurons and precursor cells that both display spontaneous $\left[\mathrm{Ca}^{2+}\right]_{\mathrm{i}}$ fluctuations. This may be reflected in the greater number of active cells seen in the VZ at E19 compared with E15 (Fig. 2C). To address this, we imaged E19 slabs and subsequently stained them for TuJ1 immunoreactivity. Many more fibers and cell bodies were stained with TuJ1 in the VZ at E19 than at E15, and a greater number of spontaneously active cells was found in regions in which there was positive TuJ1 staining (Fig. 4B, arrows on right). This result suggests that at later stages of neurogenesis the VZ can contain both precursor cells and neurons that display spontaneous $\left[\mathrm{Ca}^{2+}\right]_{\mathrm{i}}$ fluctuations.

\section{Synchronous $\left[\mathrm{Ca}^{2+}\right]_{\mathrm{i}}$ fluctuations in VZ cell pairs}

A second distinctive form of spontaneous $\left[\mathrm{Ca}^{2+}\right]_{i}$ behavior was observed in $\mathrm{VZ}$ cells at the ventricular surface. Intracellular $\mathrm{Ca}^{2+}$ fluctuations were seen in pairs of adjacent cells whose nuclei often protruded from the surface of the slab. Figure $5 \mathrm{~A}$ shows one such doublet in an E19 cortical slab before, during, and after the $\left[\mathrm{Ca}^{2+}\right]_{\mathrm{i}}$ increase. Figure $5 B$ displays a line graph of three doublet events from the same slab shown in Figure $5 A$ (arrows indicate transients shown in Fig. 5A). These events were highly synchronized; the peak of the transients occurred at the same time point, and the duration of the events were nearly identical in both cells (Fig. 5). For example, in a sample of 15 of these doublet events, the average duration of one cell of the pair was $36.7 \pm 3.1 \mathrm{sec}$, whereas the other was $37.1 \pm 3.7 \mathrm{sec}$. Doublet events were observed in tissue slabs at or near the ventricular surface at all ages examined (E15-E20).

The rounded morphology of these cells and their location at the ventricular surface suggested that they might be M-phase cells in the process of cytokinesis. By using the vital stain syto-11 to label cellular DNA (Chenn and McConnell, 1995), we found that cell doublets were in the same tissue plane as pairs of daughter cells in various stages of mitosis. For example, Figure $6 \mathrm{~A}$ shows an optical section of the ventricular surface of an E16 cortical slab stained with fluo-3. Many of the stained cells were in adjacent 


\section{A Fluo-3}

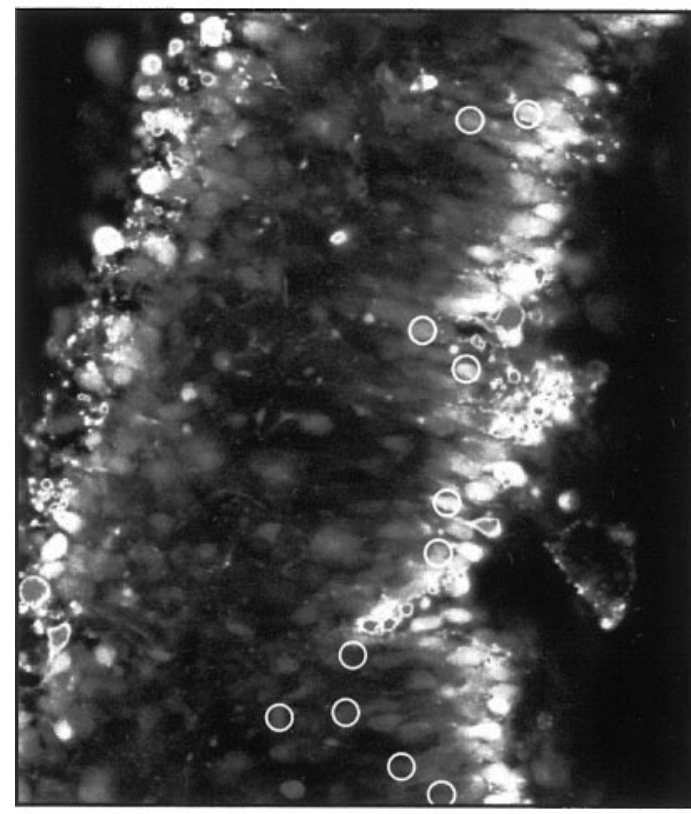

B

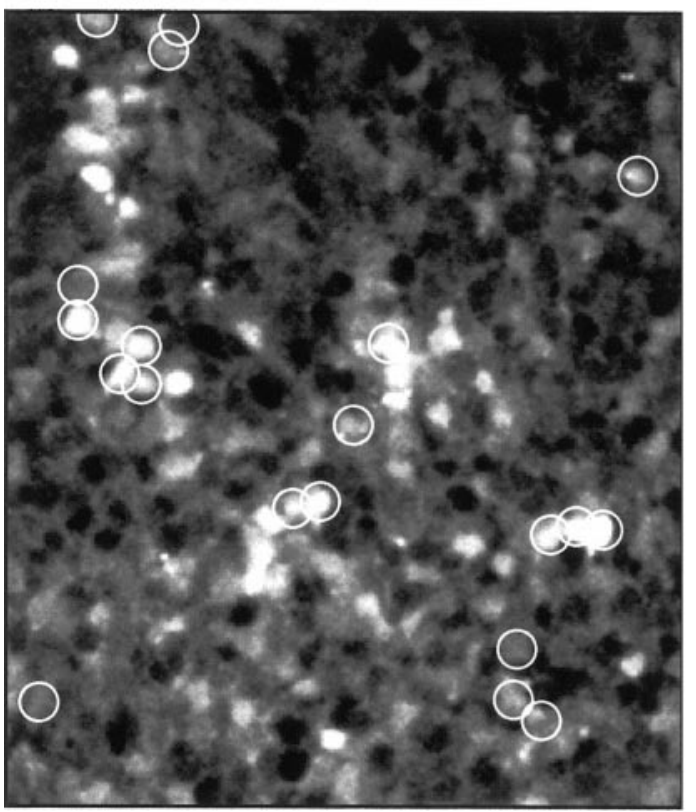

\section{Fluo-3}

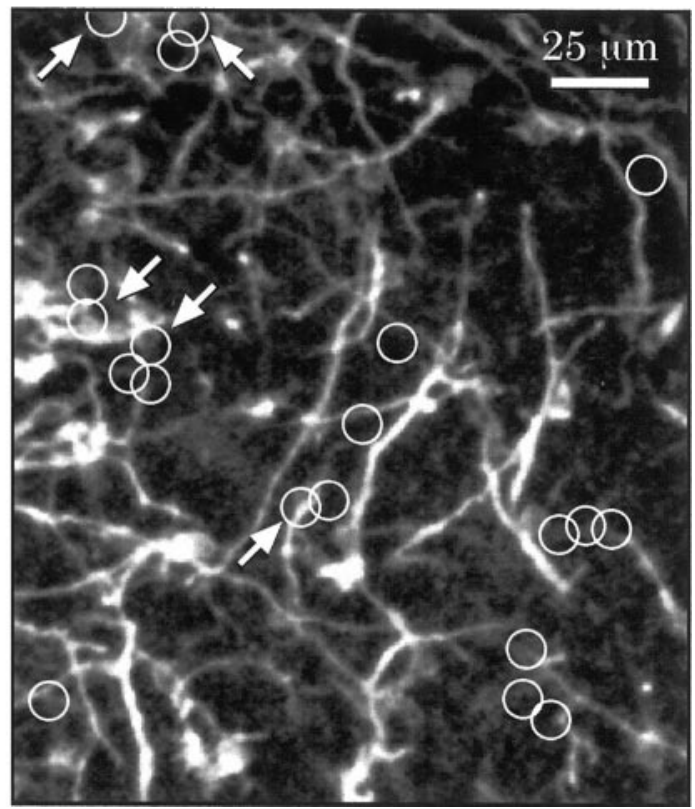

Figure 4. Most active single cells in the $V Z$ are not neurons. $A$, Coronal slice at E15 that was imaged for spontaneous $\left[\mathrm{Ca}^{2+}\right]_{\mathrm{i}}$ increases and subsequently for TuJ1 immunoreactivity. Left, A single optical section with cells active during the imaging period circled. Right, An average of 50 serial $1 \mu \mathrm{m}$ sections of the same area after processing for TuJ1 immunoreactivity. In only one case was a TuJ1-positive cell body present where an active cell was seen during $\mathrm{Ca}^{2+}$ imaging (arrow). Dashed lines approximate the boundary of the VZ. B, An E19 slab imaged for spontaneous [Ca $\left.{ }^{2+}\right]_{\mathrm{i}}$ increases and subsequently for TuJ1 immunoreactivity. Left, A single optical section $\sim 15 \mu \mathrm{m}$ from the ventricular surface with cells that were active during the imaging period circled. Right, An average of 50 serial $1 \mu \mathrm{m}$ sections of the same area after processing for TuJ1 immunoreactivity. There were many more TuJ1-labeled cells at E19 than at E15, and in several instances cells active during $\mathrm{Ca}^{2+}$ imaging were TuJ1-positive (arrows).

pairs, had rounded morphology, and displayed synchronized spontaneous $\left[\mathrm{Ca}^{2+}\right]_{i}$ fluctuations. Imaging in the same focal plane after incubation in syto-11 revealed multiple pairs of daughter cells with patterns of condensed chromatin characteristic of mitotically active cells (Fig. 6B). This pattern of staining was only observed at the ventricular surface of the slab. When focusing deeper into the VZ, only a diffuse nuclear staining was seen, a result similar to that found in slices of ferret cortex (Chenn and McConnell, 1995). Furthermore, when focusing at this deeper level, doublet events were not observed. In addition, negatively stained condensed chromatin could sometimes be seen in the nuclei of fluo-3-labeled cell doublets, as shown in the inset 
A
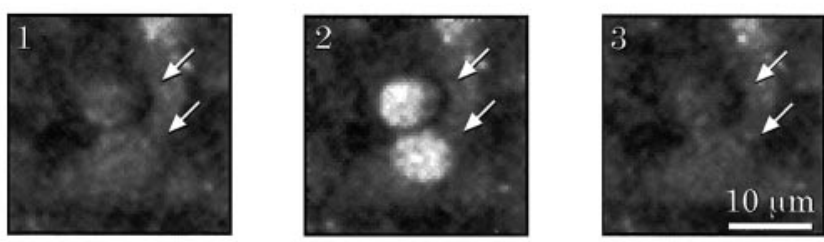

B

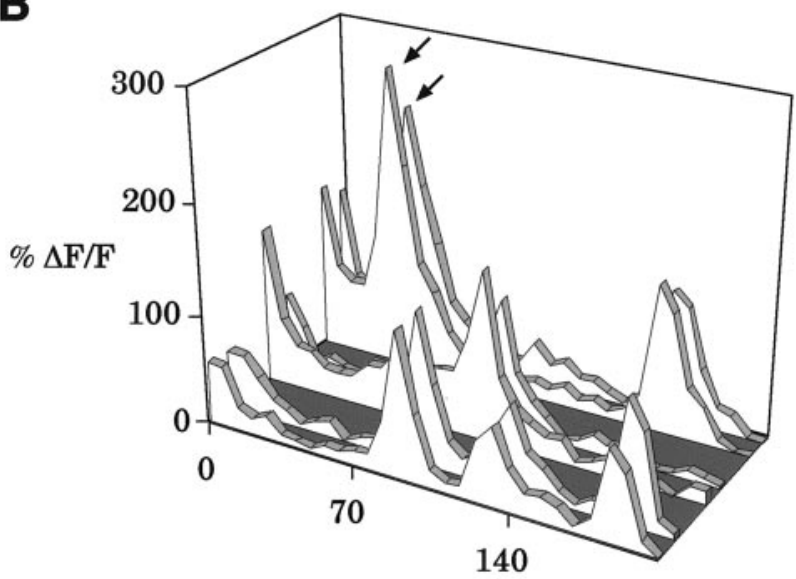

Time (sec)

Figure 5. Pairs of $\mathrm{VZ}$ cells at or near the ventricular surface show synchronized increases in $\left[\mathrm{Ca}^{2+}\right]_{\mathrm{i}} . A$, An example of a doublet event from an E19 cortical slab before $\left(A_{1}\right)$, during $\left(A_{2}\right)$, and after $\left(A_{3}\right)$ a $\left[\mathrm{Ca}^{2+}\right]_{\mathrm{i}}$ increase. $B$, A three-dimensional graphic representation of three highly synchronized doublet events. The arrows indicate transients shown in $A$. All cells are from the same slab.

of Figure $6 \mathrm{~B}$. Not surprisingly, synchronous cell pairs were also found to be TuJ1-negative (Fig. 6C). Furthermore, during long imaging trials, we were able to observe cell division (Fig. 6D). In the example illustrated in Figure $6 D_{1}$, the dividing cell first appeared rounded, but over the next $20 \mathrm{~min}$, an equatorial constriction and cleavage plane appeared in the cell, and condensed chromatin separated in a polarized manner. Changes in $\left[\mathrm{Ca}^{2+}\right]_{\mathrm{i}}$ in both daughter cells were synchronized (Fig. 6 $D_{2}$ ). These observations confirmed that at least some, if not all, cells exhibiting synchronized $\left[\mathrm{Ca}^{2+}\right]_{\mathrm{i}}$ fluctuations were mitotically active daughter cells. Finally, as with the single-cell events seen in VZ cells, doublets could occur in $\mathrm{Ca}^{2+}$-free ACSF (Fig. 6E), suggesting that these events are also mediated by the release of $\mathrm{Ca}^{2+}$ from intracellular stores.

\section{Coordinated $\left[\mathrm{Ca}^{2+}\right]_{\mathrm{i}}$ fluctuations in groups of VZ cells}

The third pattern of spontaneous $\left[\mathrm{Ca}^{2+}\right]_{\mathrm{i}}$ fluctuation consisted of coordinated $\left[\mathrm{Ca}^{2+}\right]_{\mathrm{i}}$ increases in groups of neighboring $\mathrm{VZ}$ cells. An example of such an event from an E17 neocortical slab is illustrated in Figure $7 A$. This example shows nine sequential pseudocolored images before, during, and after the coordinated event. The activity seems to originate with 1 or 2 cells (arrow) and spreads outward to $14-16$ neighboring cells. Figure $7 B$ shows the time course of $\left[\mathrm{Ca}^{2+}\right]_{\mathrm{i}}$ change in eight of these cells and the combined mean value for all cells together (inset). There was a close spatiotemporal coupling of $\left[\mathrm{Ca}^{2+}\right]_{\mathrm{i}}$ change within the cell group. In this example, the propagation rate of $\left[\mathrm{Ca}^{2+}\right]_{i}$ spread from the first cell to neighboring cells was $\sim 8 \mu \mathrm{m} / \mathrm{sec}$ (see below). These events were found to occur infrequently; over the course of our experiments, we observed 21 such events under standard imaging conditions, and in only two instances did the same cell cluster demonstrate a second coordinated $\left[\mathrm{Ca}^{2+}\right]_{\mathrm{i}}$ increase. We observed up to four spontaneous coordinated $\left[\mathrm{Ca}^{2+}\right]_{\mathrm{i}}$ events in a single cortical slab, and in all cases the events were spatially distinct. In clusters in which all or most participating cells were captured in the field of view $(n=13)$, the number of cells ranged from 4 to 20, with an average of $9.5 \pm 1.33$ cells. In cases in which the entire event duration was captured $(n=10)$, the average duration of the $\left[\mathrm{Ca}^{2+}\right]_{\mathrm{i}}$ increase was $50.1 \pm 4.37 \mathrm{sec}$. It should be noted that the cell numbers reported here are based on optical sections that cut through the radially oriented clusters at right angles (see Fig. $8 A$ ). Because the optical section samples only a portion of participating cells, the full number of cells per cluster is presumably larger. Furthermore, we observed several of these events while imaging the $\mathrm{VZ}$ in brain slices (Fig. $8 C_{2}$ ). They involved groups of cells oriented radially that spanned several cell diameters within the VZ.

These events resemble previously described coordinated $\left[\mathrm{Ca}^{2+}\right]_{\mathrm{i}}$ fluctuations termed "neuronal domains" observed in neonatal cortical neurons in which $\mathrm{Ca}^{2+}$ or a related second messenger is thought to propagate the $\left[\mathrm{Ca}^{2+}\right]_{\mathrm{i}}$ signal by passing through gap junction channels and triggering release of $\left[\mathrm{Ca}^{2+}\right]_{i}$ from intracellular stores (Yuste et al., 1992, 1995). Coordinated events in the $\mathrm{VZ}$ also depend on $\mathrm{Ca}^{2+}$ release from intracellular stores. We observed several cluster events in tissue slabs from experiments with $0 \mathrm{Ca}^{2+} / 2 \mathrm{~mm}$ EGTA in the bathing solution. These events were similar to those seen under standard conditions. The number of cells per cluster ranged from 5 to 23 with an average of $11 \pm 4.1$ cells $(n=4)$, and in clusters in which we resolved the entire event, the average duration was $55.7 \pm 8.2 \mathrm{sec}(n=3)$. In three clusters in $\mathrm{Ca}^{2+}$-free solution, images were captured fast enough to estimate the rate of $\left[\mathrm{Ca}^{2+}\right]_{i}$ propagation. Figure $7 C_{1}$ shows a cluster event (approximately nine cells total) with the putative trigger cell (cell 1) and two follower cells (cells 2 and 3) labeled. Figure $7 C_{2}$ shows the activity graph for all of the cells in the cluster. By measuring the distance of each follower cell from the trigger cell and the time of onset of $\left[\mathrm{Ca}^{2+}\right]_{i}$ increase in each of these cells, we could estimate the rate of signal propagation (Fig. $7 C_{2}$, inset). Using this method, we found that these events propagated at an average rate of $6.8 \pm 2.0 \mu \mathrm{m} / \mathrm{sec}$ (range, 2.4$15.2 \mu \mathrm{m} / \mathrm{sec}$ ). This is in the range of speeds found for diff usion of $\mathrm{Ca}^{2+}$ or related second messengers through gap junction-coupled cells (Cornell-Bell and Finkbeiner, 1991; Meyer, 1991; Yuste et al., 1995; Newman and Zahs, 1997). These results suggest that cluster events are mediated by intracellular $\mathrm{Ca}^{2+}$ release and most likely propagate by diffusion of $\mathrm{Ca}^{2+}$ or other messengers through gap junction channels.

Because of their infrequent occurrence, we performed several manipulations to determine whether we could trigger cluster events or increase their frequency. We lowered the temperature of the bath solution by several degrees, a technique that has been used to trigger neuronal domains (Yuste et al., 1995). Decreasing the bath ACSF from 21 to $16^{\circ} \mathrm{C}$ by adding chilled ACSF at the standard perfusion rate or by adding a bolus of chilled ACSF did not produce spontaneous cluster activity. Imaging trials performed in $\mathrm{ACSF}$ warmed to $32-34^{\circ} \mathrm{C}$ also produced no increase in cluster behavior. Attempts to trigger the cluster events by incubating tissue in low concentrations of caffeine (100-500 $\mu \mathrm{M})$ also did not trigger cluster events. We removed extracellular $\mathrm{Mg}^{2+}$ 
A

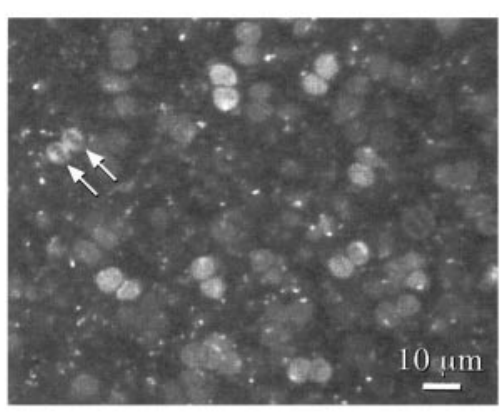

D

1

Figure 6. Synchronously active cell pairs are M-phase cells in the process of cell division. $A, \mathrm{~A}$ fluo-3-loaded E16 slab imaged at the ventricular surface. Notice the presence of a great many cells apparently in the state of mitosis. $B$, Syto-11 staining and imaging of the VZ surface displaying patterns of condensed chromatin. The inset shows condensed chromatin visible with fluo-3 loading in the doublet indicated by arrows in $A$. $C$, Doublet event (arrows) in an E19 slab during $\mathrm{Ca}^{2+}$ imaging $\left(C_{1}\right)$ and after subsequent $\mathrm{TuJ} 1$ staining $\left(C_{2}\right)$, demonstrating that doublets are not neurons. $D_{1}$, A dividing E17 VZ cell observed over a $20 \mathrm{~min}$ period. Each image (1-4) is separated by $\sim 5 \mathrm{~min}$. $\mathrm{D}_{2}$, Spontaneous fluctuations in $\left[\mathrm{Ca}^{2+}\right]_{\mathrm{i}}$ that were synchronized in both daughter cells. $E$, Doublets occurring in $\mathrm{Ca}^{2+}$-free ACSF, suggesting that these events are mediated by the release of $\mathrm{Ca}^{2+}$ from intracellular stores. Inset shows images before (1), during (2), and after (3) the doublet event.
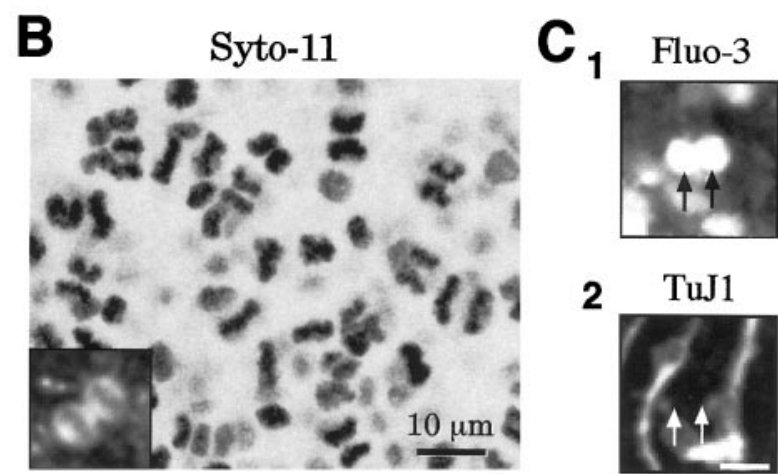

2

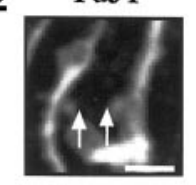

$10 \mu \mathrm{m}$
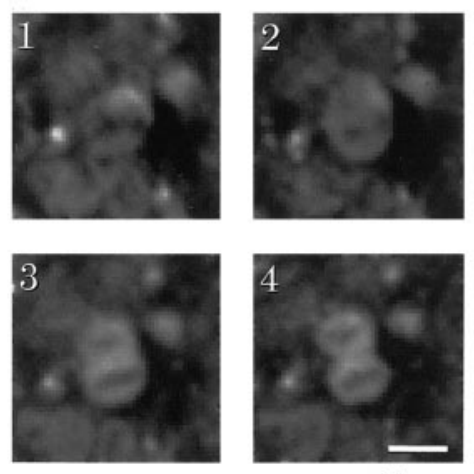

$10 \mu \mathrm{m}$
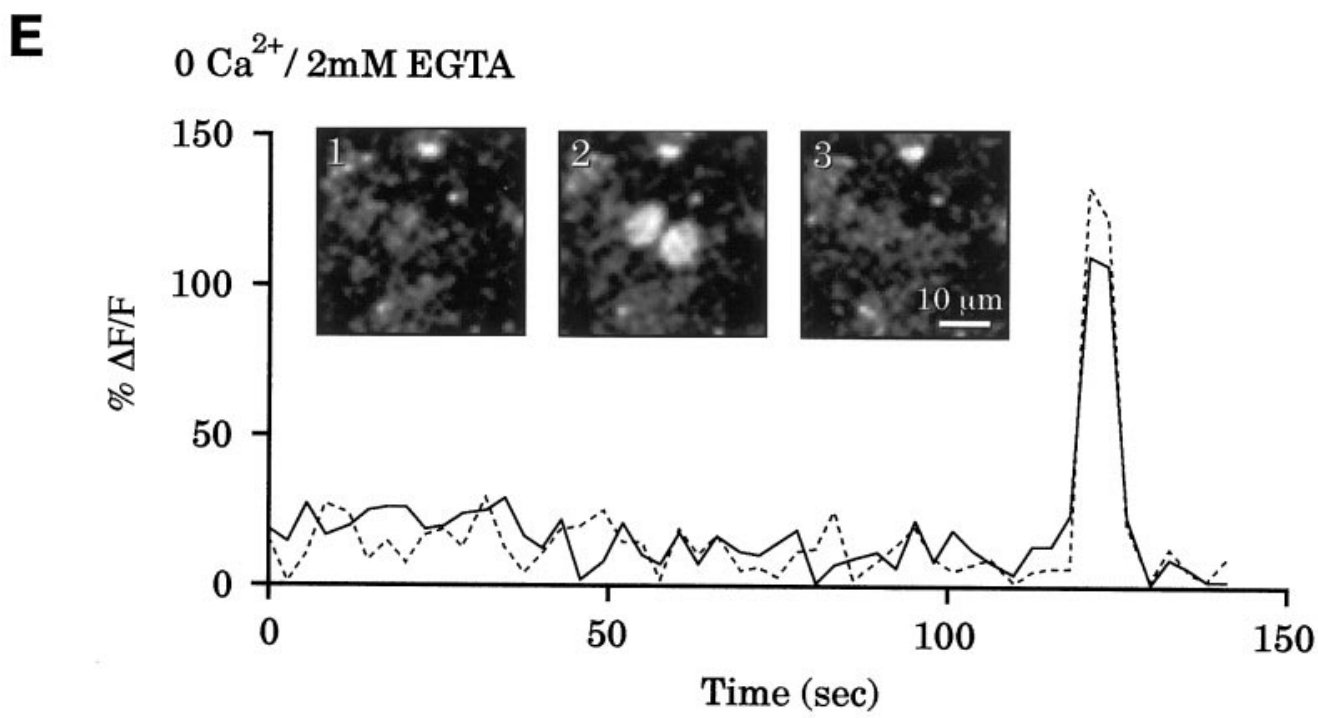

Figure 7. Top. Coordinated increases in $\left[\mathrm{Ca}^{2+}\right]_{\mathrm{i}}$ occur in clusters of neighboring VZ cells. $A$, A spontaneously active VZ cluster at E17. This example shows nine sequential pseudocolored images taken every $4 \mathrm{sec}$ before, during, and after a cluster event. $B$, The time course of the $\left[\mathrm{Ca}{ }^{2+}\right]_{\mathrm{i}}$ change plotted for eight of the cells from the cluster shown in A. Arrow indicates putative trigger cell. The time course of the mean value for all of the cells is shown in the inset. $C$, Coordinated cell activity occurring in $\mathrm{Ca}^{2+}$-free ACSF and propagating at $\sim 10 \mu \mathrm{m} / \mathrm{sec}$. $C_{1}$, A cluster event in Ca ${ }^{2+}$-free/2 mM EGTA ACSF with a putative trigger cell (cell 1 ) and two follower cells (cells 2 and 3) labeled. $C_{2}$, Activity graph for all of the cells in the cluster with the onset of the $\mathrm{Ca}^{2+}$ transients for the three labeled cells displayed in the inset. Measuring the distance of each follower cell from the trigger cell and the time of onset of the $\left[\mathrm{Ca}^{2+}\right]_{\mathrm{i}}$ increase in each cell allowed estimation of the rate of signal propagation.

Figure 8. Bottom. Cells demonstrating coordinated $\left[\mathrm{Ca}^{2+}\right]_{\mathrm{i}}$ increases correspond to groups of gap junction-coupled $V Z$ cells. $A$, A schematic diagram of the radial arrangement of a coupled $V Z$ cell cluster. The focal plane of the confocal microscope is indicated by shading. The recorded cell is shown with a schematic electrode. $B$, A confocal image of a section through a dye-stained (pseudocolored) cell cluster at E17. Multiple cells are dye-filled after injection of a single $V Z$ cell (arrow). $C$, Spontaneously active cell clusters that do not include TuJ1-positive cells. $C_{1}$, An average of 20 serial $2 \mu \mathrm{m}$ sections through an E16 coronal slice stained for TuJ1 after $\mathrm{Ca}^{2+}$ imaging. A coordinated $\mathrm{Ca}^{2+}$ increase was observed in a cluster of cells located within the box. $C_{2}$, Fluo-3-stained image showing the peak $\left[\mathrm{Ca}^{2+}\right]_{\mathrm{i}}$ increase for the spontaneously active cell cluster from the area highlighted by the box in $C_{1}$. $C_{3}$, An average of three serial $2 \mu \mathrm{m}$ sections of the area shown in $C_{2}$ after TuJ1 staining. There was no obvious correspondence between TuJ1-stained cells and cells participating in the coordinated $\left[\mathrm{Ca}^{2+}\right]_{\mathrm{i}}$ increase. 
A

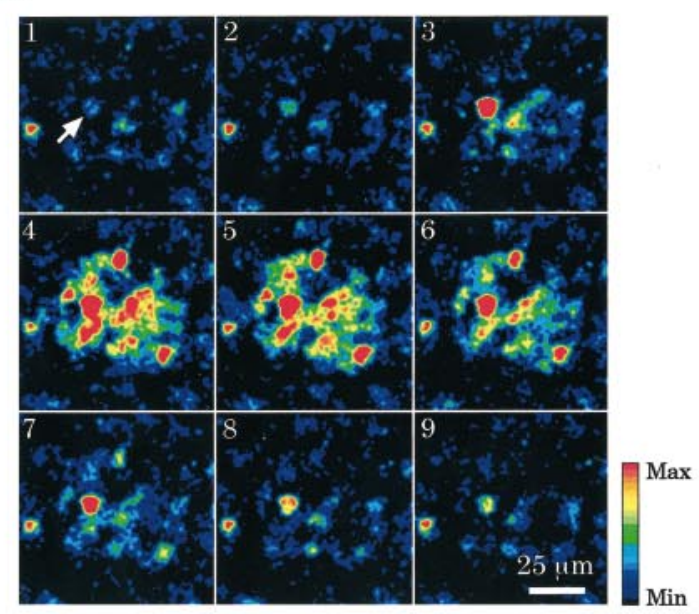

B

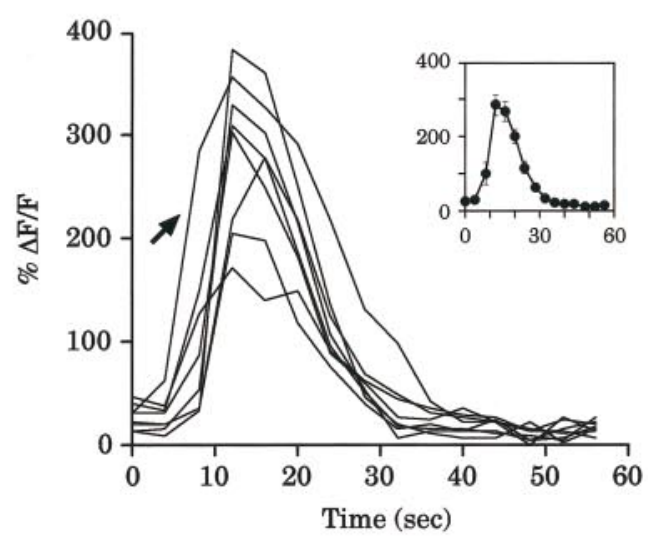

\section{C} 1

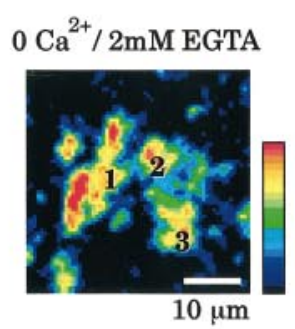

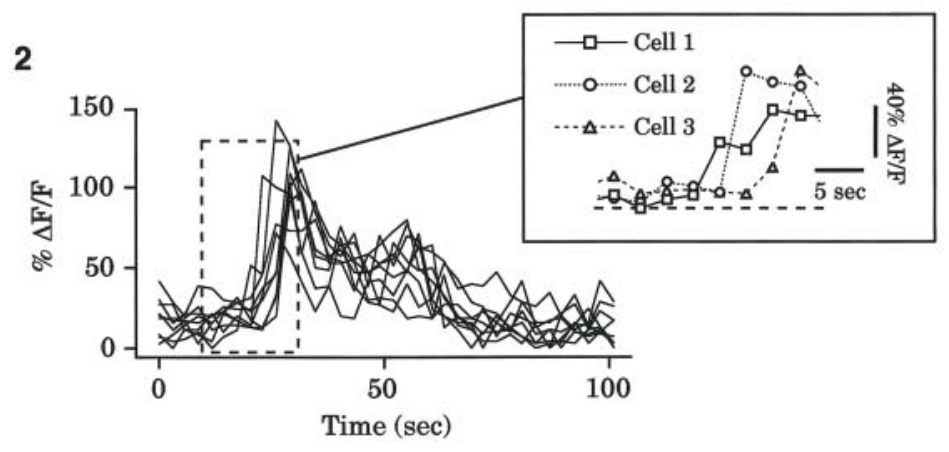

A

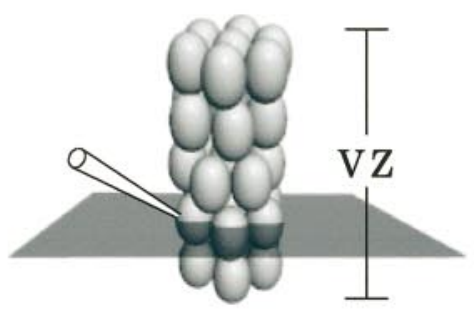

C

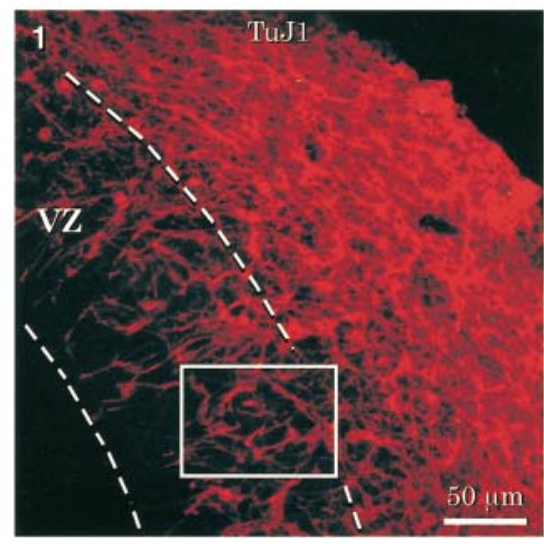

B

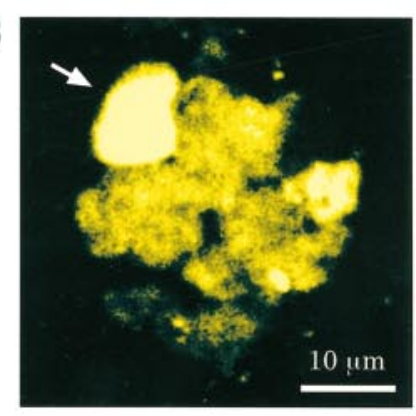

2

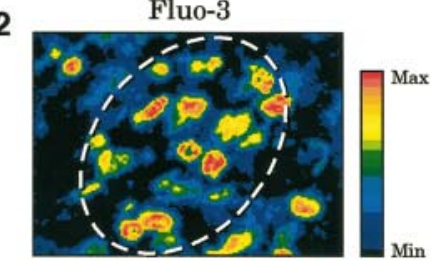

3

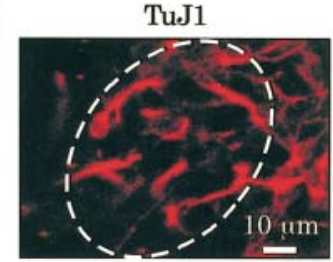

Legend continues. 
from the bathing solution, another manipulation that has been reported to increase the frequency of neuronal domains in the neocortex (Yuste et al., 1995). Although we did observe several cluster events while imaging under this condition, clusters still occurred infrequently and at random. Overall, we found no manipulations that could trigger cluster events in the VZ.

Based on the resemblance of these cell clusters to clusters of gap junction-coupled cells described previously in the embryonic rat VZ (LoTurco and Kriegstein, 1991), we suspected that the coordinated $\left[\mathrm{Ca}^{2+}\right]_{\mathrm{i}}$ fluctuations were occurring in precursor cells coupled by gap junction channels. Because of the random and infrequent occurrence of $\left[\mathrm{Ca}^{2+}\right]_{\mathrm{i}}$ transients in clusters and our inability to evoke them, we were unable to examine the effect of gap junction channel-blocking agents on cluster transients. Instead, the relationship between clusters of cells demonstrating spontaneous $\left[\mathrm{Ca}^{2+}\right]_{\mathrm{i}}$ transients and gap junction-coupled cell clusters was examined indirectly by comparing their morphological features. Single E17 VZ cells were dye-filled using microelectrodes filled with the impermeant $\mathrm{K}^{+}$-salt of fluo-3 (Fig. 8A). Clusters of adjacent stained cells could be visualized from the VZ surface (Fig. $8 B ; n=4$ ), indicating the passage of the dye through gap junction channels. Although these filled clusters were not spontaneously active, the number of cells and their spatial arrangement were very similar to that of the clusters of cells participating in spontaneous coordinated $\left[\mathrm{Ca}^{2+}\right]_{i}$ transients (compare Fig. $7 A$ with Fig. $8 B$ ).

Gap junction-coupled cell clusters in the VZ have been shown to be composed of proliferating neuroepithelial cells in all phases of the cell cycle except M (Bittman et al., 1997). In addition, the majority of VZ clusters include at least one radial glia cell but not TuJ1-positive neurons (Bittman et al., 1997). If the spontaneously active clusters seen in this study correspond to gap junctioncoupled clusters, then we would predict that the cells are TuJ1negative. There were only a few cluster events in experiments in which $\mathrm{Ca}^{2+}$ imaging was followed by TuJ1 staining, and in only one case were we confident that the same anatomical areas could be compared. Figure $8 C_{1}$ shows an E16 slice stained for TuJ1 with the area in which the cluster event occurred highlighted by a box. Figure $8 C_{2}$ shows the cluster event near the peak of the $\mathrm{Ca}^{2+}$ transient, with the extent of the event outlined. The event extended radially for several cell diameters. Figure $8 C_{3}$ shows the corresponding area stained for $\mathrm{TuJ} 1$. When overlaid, we found no obvious correspondence between the spontaneously active cells and TuJ1-positive cells. In addition, in single optical sections of TuJ1-stained slabs, there were no cases of multiple adjacently labeled neurons in the VZ, as would be expected for cells belonging to spontaneously active clusters (data not shown). Within the VZ, only proliferating precursor cells have multiple closely apposed somata that could comprise an active cell cluster (see Fig. $1 B$ ). These events therefore most likely occur in gap junctioncoupled precursor cells in the VZ.

\section{Spontaneous $\left[\mathrm{Ca}^{2+}\right]_{\mathrm{i}}$ fluctuation in immature neurons}

To address the issue of whether patterns of spontaneous $\left[\mathrm{Ca}^{2+}\right]_{i}$ fluctuation change after exit from the cell cycle, we also imaged cells in the IZ, marginal zone (MZ), and CP of the embryonic cortex, regions that contain mostly postmitotic neurons. In addition to single cells displaying spontaneous $\left[\mathrm{Ca}^{2+}\right]_{i}$ events with similar kinetics to those described in the VZ, we found that many cells in these regions produced transients at much higher frequencies. Consistent with previous findings (Menezes and Luskin, 1994), we found that these regions show high levels of TuJ1 staining. Figure $9 A_{1}$ shows the MZ of an E15 cortical slice during $\mathrm{Ca}^{2+}$ imaging (left) and after TuJ1 staining (right). The MZ was intensely stained for TuJ1. Many cells in this region were highly active, showing multiple spontaneous $\left[\mathrm{Ca}^{2+}\right]_{\mathrm{i}}$ fluctuations over a 5 min imaging period. An example of one such cell is shown in Figure $9 A_{2}$. In the MZ, many of the active cells had elongated horizontally oriented cell bodies that were bipolar (Fig. $9 A_{1}$, arrows on left). These features are reminiscent of Cajal-Retzius cells, a population of early generated neurons commonly found in the MZ of the developing neocortex (Bayer and Altman, 1991). Likewise, radially oriented presumptive neurons in the CP (data not shown) were highly active. Figure $9 B$ shows the activity plot of an E16 CP cell demonstrating multiple $\left[\mathrm{Ca}^{2+}\right]_{\mathrm{i}}$ transients. In a number of cases, we also observed cells in the IZ that displayed multiple spontaneous $\left[\mathrm{Ca}^{2+}\right]_{\mathrm{i}}$ fluctuations. Figure $9 C_{1}$ shows an example of one such cell both during $\mathrm{Ca}^{2+}$ imaging and after TuJ1 staining; the corresponding activity graph for this cell is shown in Figure $9 C_{2}$. These experiments suggest that as cells become terminally postmitotic and migrate away from the VZ, they continue to undergo spontaneous $\left[\mathrm{Ca}^{2+}\right]_{i}$ fluctuations; however, the fluctuations are often more frequent.

Previous results have shown that individual neurons in the early postnatal cortex display $\left[\mathrm{Ca}^{2+}\right]_{\mathrm{i}}$ fluctuations either spontaneously (Owens et al., 1996) or when exposed to very low concentrations of glutamate receptor agonists (Yuste and Katz, 1991). These events can be sensitive to TTX and blockers of VGCCs (Yuste and Katz, 1991; Owens et al., 1996), suggesting mediation via neuronal activity and VGCC activation. Consistent with these findings, we observed that the spontaneous $\left[\mathrm{Ca}^{2+}\right]_{i}$ fluctuations seen in some cells of the embryonic $\mathrm{CP}$ and $\mathrm{MZ}$ can be either blocked entirely or significantly reduced after removing extracellular $\mathrm{Ca}^{2+}$ (Fig. 9D). These observations suggest that after exit from the cell cycle, some neurons undergo a developmental change in the mechanism as well as the dynamics of their spontaneous $\left[\mathrm{Ca}^{2+}\right]_{\mathrm{i}}$ fluctuations.

\section{DISCUSSION}

This study describes patterns of spontaneous $\left[\mathrm{Ca}^{2+}\right]_{\mathrm{i}}$ fluctuation in neocortical VZ cells in situ. A schematic diagram of the cell types demonstrating the different patterns of spontaneous $\left[\mathrm{Ca}^{2+}\right]_{\mathrm{i}}$ fluctuations is shown in Figure 10 (see figure legend for details). Studies of cellular behavior in situ are particularly important to help unravel signaling mechanisms in a spatially complex structure such as the VZ that is both stratified and composed of columnar compartments. For example, coupling of VZ cells into columnar clusters seems to be necessary for cells to progress through the cell cycle in situ (Bittman et al., 1997), and the orientation of the cleavage plane of M-phase cells, a feature that can only be observed in situ, seems to be important for determining whether cells re-enter the cell cycle or become terminally postmitotic (Chenn and McConnell, 1995).

\section{Spontaneous $\left[\mathrm{Ca}^{2+}\right]_{i}$ fluctuation in VZ cells}

Fluctuations in $\left[\mathrm{Ca}^{2+}\right]_{\mathrm{i}}$ in cortical precursor cells could have several potential roles including regulation of cell cycle progression. Transient increases in $\left[\mathrm{Ca}^{2+}\right]_{\mathrm{i}}$ are associated with nuclear envelope breakdown, chromatin condensation, and the onset of anaphase in sea urchin eggs (Poenie et al., 1985) and cultured animal cells (Keith et al., 1985; Kao et al., 1990). Cells make a commitment to divide by crossing from $\mathrm{G}_{1}$ to $\mathrm{S}$ phase and initiating DNA synthesis, a transition that is often environmentally regulated (Murray and Hunt, 1993) and associated with $\left[\mathrm{Ca}^{2+}\right]_{\mathrm{i}}$ 
A

1
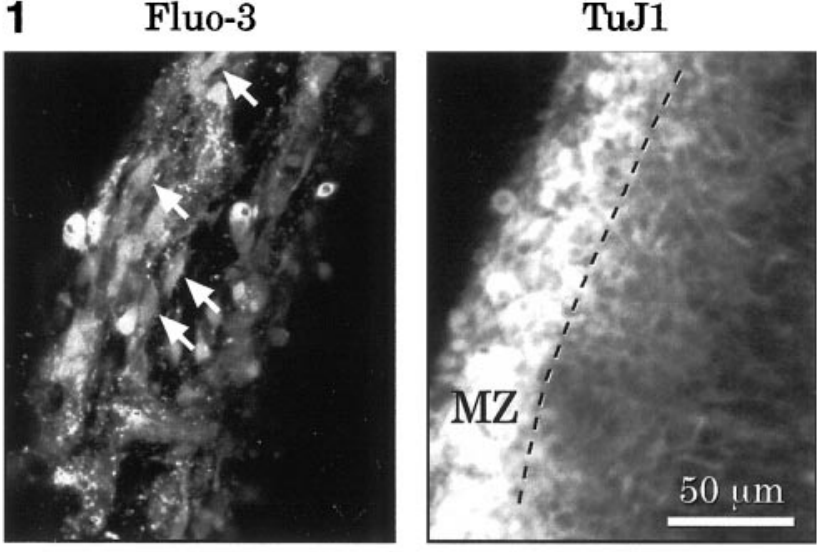

2

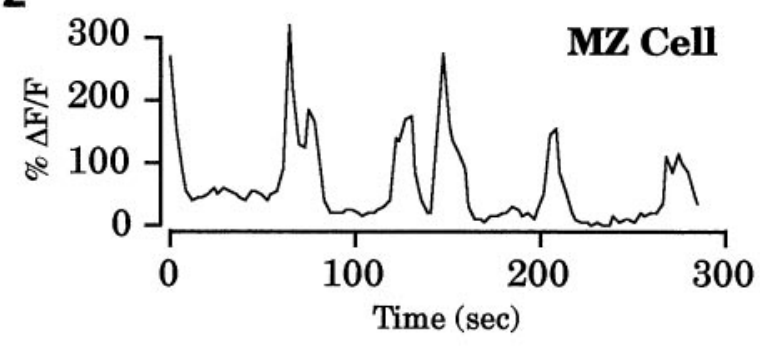

B

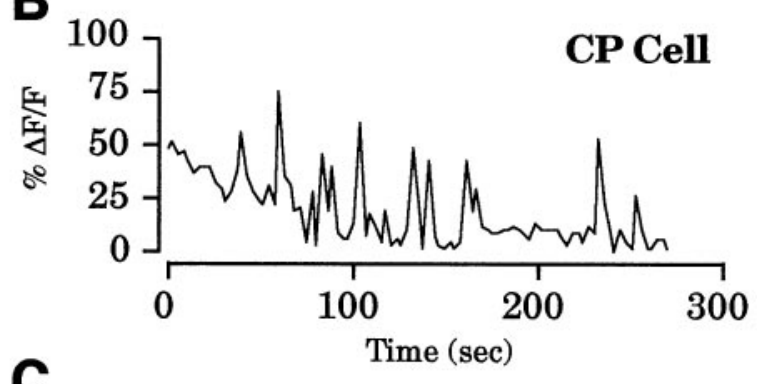

C 1

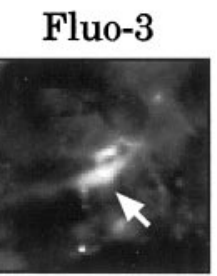

2

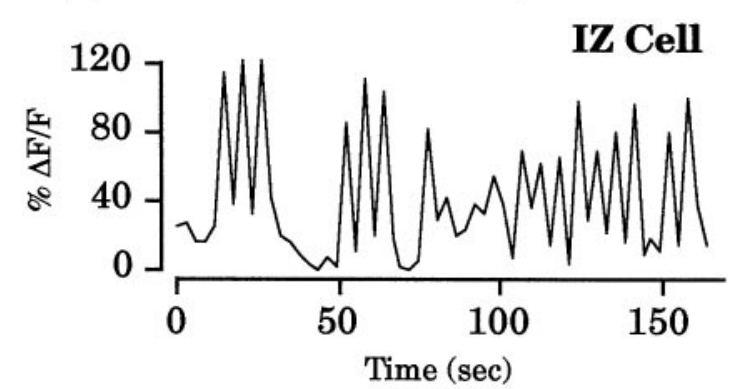

D MZ Cell

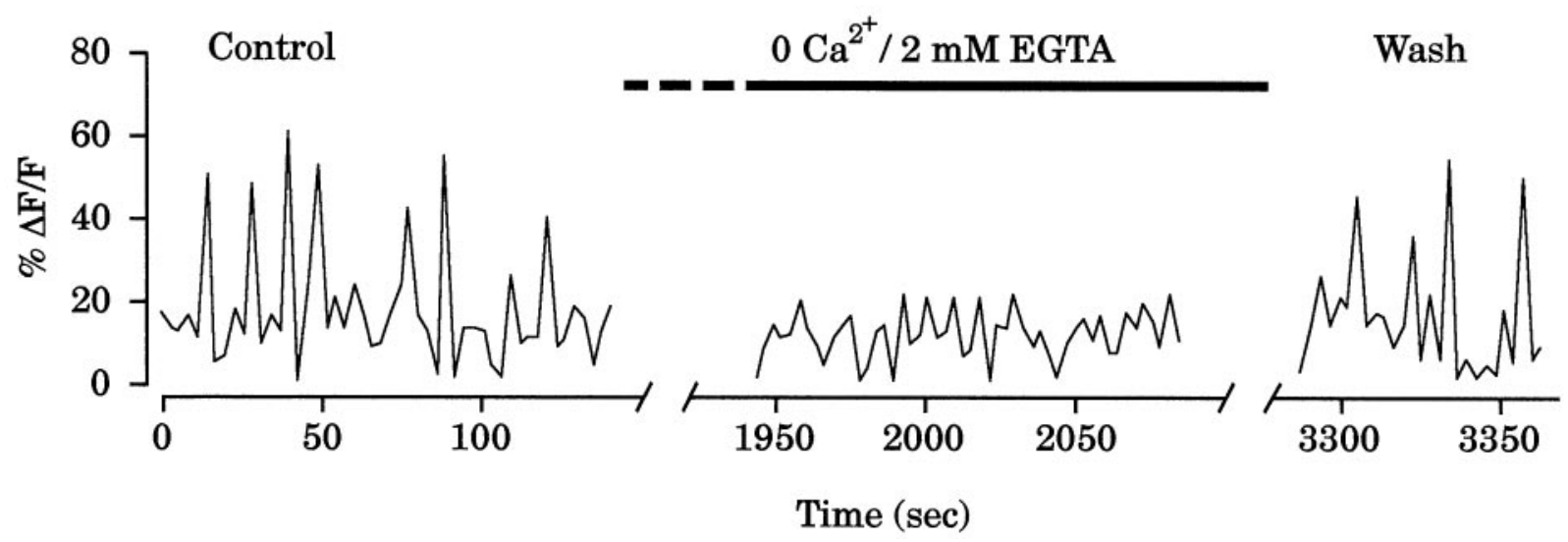

Figure 9. Spontaneous $\left[\mathrm{Ca}^{2+}\right]_{\mathrm{i}}$ fluctuations in developing neurons. $A_{1}, M Z$ of an E15 cortical slice during $\mathrm{Ca}^{2+}$ imaging (left) and after TuJ1 staining (right). The $M Z$ contained many active cells, some of which had the morphological features of Cajal-Retzius neurons (arrows), and contained a high density of TuJ1-stained cells. $A_{2}$, Activity graph of an $M Z$ cell shown in $A_{1} . B$, Activity graph of an E16 $C P$ cell. $C_{1}$, Presumptive migrating neuron in the IZ (arrows) of an E16 coronal brain slice during $\mathrm{Ca}^{2+}$ imaging (left) and after TuJ1 staining (right). Pial surface is to the top right-hand corner. $C_{2}$, Activity graph of the cell shown in $C_{1}$. D, An E17 MZ cell recorded in $\mathrm{Ca}^{2+}(2 \mathrm{~mm}) \mathrm{ACSF}$ and after $\sim 30$ min of perfusion with Ca ${ }^{2+}$-free ACSF. Transients failed to appear in the $\mathrm{Ca}^{2+}$-free condition but returned once normal ACSF was reperfused (Wash).

transients (Lu and Means, 1993). Beyond the critical $\mathrm{G}_{1}$ to $\mathrm{S}$ transition, cell cycle progression is presumably autonomous, and no further external signals are required (Reddy, 1994). Most of the cells reported here are within several cell diameters of the ventricular surface, and as a result of interkinetic nuclear migration, they are in $\mathrm{G}_{2}, \mathrm{M}$, or early $\mathrm{G}_{1}$. Our results show that $\left[\mathrm{Ca}^{2+}\right]_{\mathrm{i}}$ fluctuations in these cells are not regulated by neuronal activity, ionotropic GABA and glutamate receptor activation, or activation of VGCCs but do not eliminate the possibility that $\left[\mathrm{Ca}^{2+}\right]_{\mathrm{i}}$ fluctuations in late $G_{1}$ to $S$-phase cells are regulated and/or induced by these signals. In addition, contact-dependent signals and short-range diffusible factors such as neurotrophins may also influence $\left[\mathrm{Ca}^{2+}\right]_{\mathrm{i}}$. For example, proliferation of cortical precursor cells can be stimulated by basic fibroblast growth factor (bFGF) (Ghosh and Greenberg, 1995), and many growth factors including bFGF act via tyrosine kinase receptors that in turn can lead to release of $\mathrm{Ca}^{2+}$ from intracellular stores (Ullrich and Schlessinger, 1990; Pende et al., 1997). 


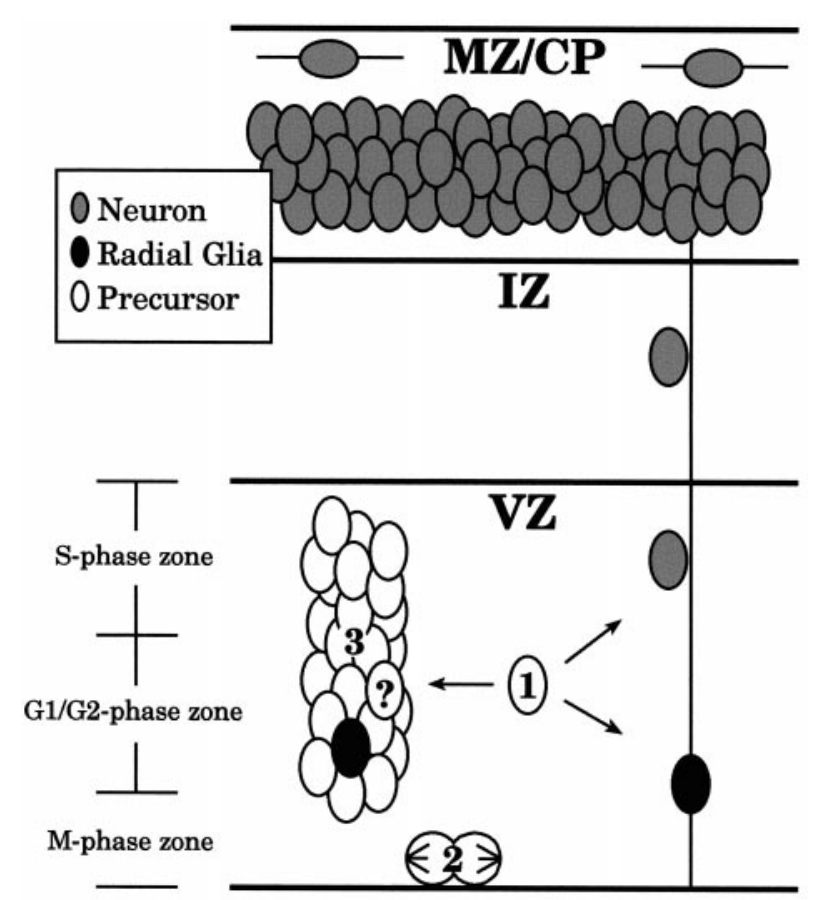

Figure 10. Schematic of cell types demonstrating different patterns of spontaneous $\left[\mathrm{Ca}^{2+}\right]_{\mathrm{i}}$ fluctuations. Numbers refer to cells demonstrating single-cell events (1), double-cell events (2), and coordinated multicell cluster events (3). Single active cells are primarily TuJ1-negative proliferative cells but could also include members of clusters that display independent $\left[\mathrm{Ca}^{2+}\right]_{\mathrm{i}}$ fluctuations (?) and postmitotic neurons in the process of migration, particularly during the later stages of neurogenesis. Single-cell activity might also include radial glia cells. Cell pairs demonstrating synchronized activity are mitotically active precursor cells. Active cell clusters correspond to groups of gap junction-coupled cells that include precursor cells in $\mathrm{G}_{1}, \mathrm{G}_{2}$, and $\mathrm{S}$ and at least one radial glia cell. Spontaneous $\left[\mathrm{Ca}^{2+}\right]_{\mathrm{i}}$ fluctuations are also seen in neurons of the $I Z, C P$, and MZ (shaded cells).

If the observed $\left[\mathrm{Ca}^{2+}\right]_{\mathrm{i}}$ transients are influencing cell cycle events, it is possible that the developmental changes in the behavior of the $\left[\mathrm{Ca}^{2+}\right]_{\mathrm{i}}$ transients may reflect developmental changes in the cell cycle. In mouse, the neocortical neurogenic interval has been well characterized (Caviness et al., 1995). During neurogenesis, there is a progressive increase in the duration of the cell cycle and an increase in the number of cells exiting the cell cycle. The observed increase in the number of active cells and the frequency of spontaneous $\left[\mathrm{Ca}^{2+}\right]_{\mathrm{i}}$ fluctuations between E15 and E19 may reflect these developmental changes in cell cycle parameters.

The close match between the location and appearance of cell pairs demonstrating synchronized $\left[\mathrm{Ca}^{2+}\right]_{\mathrm{i}}$ fluctuations and cells in mitosis, as demonstrated by syto- 11 staining, indicates that doublet cells are near the end of the cell division cycle. This was confirmed in time-lapse studies of doublet cells undergoing division. Transient increases in $\left[\mathrm{Ca}^{2+}\right]_{\mathrm{i}}$ have been associated with the onset of cytokinesis and with the activation of actomyosin filaments that serve to separate daughter cells at the end of telophase (Ratan et al., 1988; Whitfield et al., 1995). The $\left[\mathrm{Ca}^{2+}\right]_{\mathrm{i}}$ increases observed in doublets could be associated with either of these cell cycle events. Furthermore, recent data from studies of dividing cells in the rat VZ have demonstrated that mitotic spindles are highly motile (Adams, 1996), and the $\left[\mathrm{Ca}^{2+}\right]_{\mathrm{i}}$ transients seen during doublet events could possibly serve to influence these movements. The finding that $\left[\mathrm{Ca}^{2+}\right]_{\mathrm{i}}$ oscillations in doublets are always synchronous is probably because of the passage of $\left[\mathrm{Ca}^{2+}\right]_{\mathrm{i}}$ or second messengers through the relatively large cytoplasmic bridges that couple dividing daughter cells.

Another potential role of $\left[\mathrm{Ca}^{2+}\right]_{\mathrm{i}}$ fluctuations in VZ cells could be to regulate gap junction coupling. Cell coupling in the VZ is dynamic; proliferative cells in the VZ uncouple from clusters before $M$ phase and recouple in $G_{1}$ or $S$ phase to progress through the cell cycle (Bittman et al., 1997). The permeability of gap junction channels is also dynamic and can be regulated by intracellular $\mathrm{Ca}^{2+}$ levels (Turin and Warner, 1977; Spray et al., 1981). Fluctuations in $\left[\mathrm{Ca}^{2+}\right]_{\mathrm{i}}$ could therefore be involved in the regulation of gap junction permeability and could underlie the dynamic changes observed in VZ cell coupling.

\section{Coordinated $\left[\mathrm{Ca}^{2+}\right]_{\mathrm{i}}$ increase in VZ cell clusters}

The observations presented here that VZ cell clusters undergo spontaneous coordinated fluctuations in $\left[\mathrm{Ca}^{2+}\right]_{\mathrm{i}}$ suggest that gap junction-coupled clusters in the VZ may act as functional units and that synchronized $\left[\mathrm{Ca}^{2+}\right]_{\mathrm{i}}$ increases may coordinate intercellular signaling among cluster members. A possible role of such coordinated transients might be to synchronize cell cycle events. Experiments based on clonal analysis and birthdate labeling also indicate that small groups of adjacent cortical precursor cells, similar in size to the gap junction-coupled cell clusters, pass through the cell cycle in relative synchrony (Reznikov and van der Kooy, 1995; Cai et al., 1997). We hypothesize that these synchronously cycling cells may belong to individual gap junctioncoupled VZ cell clusters. If true, this would support a role for coupling and possibly coordinated $\left[\mathrm{Ca}^{2+}\right]_{\mathrm{i}}$ increases in cell cycle synchronization.

Coordinated changes in $\left[\mathrm{Ca}^{2+}\right]_{\mathrm{i}}$ in groups of adjacent cells have been described in a variety of intact tissue preparations. In addition to the cluster events described in this study, spontaneous increases in $\left[\mathrm{Ca}^{2+}\right]_{\mathrm{i}}$ have been reported in groups of gap junction coupled neurons in the developing postnatal cortex (Yuste et al., 1992, 1995), and spontaneous waves of $\left[\mathrm{Ca}^{2+}\right]_{\mathrm{i}}$ increase have been reported in neighboring neurons in the developing retina (Wong et al., 1995; Feller et al., 1996). Coordinated $\left[\mathrm{Ca}^{2+}\right]_{\mathrm{i}}$ increases thus seem to be a general feature of developing postnatal CNS neurons (Yuste, 1997). It has been proposed that coordinated $\mathrm{Ca}^{2+}$ signaling via gap junction channels observed in cortical neurons may be involved in synaptic circuit development (Peinado et al., 1993b; Kandler and Katz, 1995; Katz and Shatz, 1996), but the role of gap junction coupling in precursor cells in the $\mathrm{VZ}$ is likely to serve a completely different function possibly more analogous to the role of coupling in other populations of proliferating cells (Guthrie and Gilula, 1989). It is noteworthy that after terminal mitosis, uncoupled neurons migrate to the cortical plate, recouple perinatally, and once again undergo coordinated $\left[\mathrm{Ca}^{2+}\right]_{\mathrm{i}}$ increases (Yuste et al., 1992; Peinado et al., 1993a; Bittman et al., 1997). It is interesting to speculate that an individual postnatal neuronal domain may consist of neurons whose clonal antecedents were once coupled together within the VZ.

\section{Spontaneous $\left[\mathrm{Ca}^{2+}\right]_{\mathrm{i}}$ fluctuation in immature neurons}

At least some of the cells exhibiting single-cell events in the VZ at late embryonic ages are likely to be postmitotic neurons. Distinct patterns of spontaneous $\left[\mathrm{Ca}^{2+}\right]_{\mathrm{i}}$ fluctuations have been described for postmitotic neurons during early stages of migration and differentiation in other experimental systems. Intermittent $\left[\mathrm{Ca}^{2+}\right]_{i}$ increases associated with periods of migrational move- 
ment have been observed in cerebellar granule cells (Komuro and Rakic, 1996). Both $\mathrm{Ca}^{2+}$ influx and release of $\mathrm{Ca}^{2+}$ from intracellular stores contribute to the $\left[\mathrm{Ca}^{2+}\right]_{\mathrm{i}}$ fluctuation associated with granule cell migration (Komuro and Rakic, 1996). Calcium transients associated with cell movement have also been observed in cultured cortical neurons (Behar et al., 1996). Some of the single-cell $\left[\mathrm{Ca}^{2+}\right]_{\mathrm{i}}$ oscillations observed in the $\mathrm{VZ}$ could therefore be early $\left[\mathrm{Ca}^{2+}\right]_{\mathrm{i}}$ surges that act to propel cells during migration.

After migration out of the VZ, postmitotic neurons in the $\mathrm{MZ}$ and $\mathrm{CP}$ continue to exhibit spontaneous $\left[\mathrm{Ca}^{2+}\right]_{\mathrm{i}}$ fluctuations. These events could serve to influence the differentiation of immature neurons. Calcium transients have been associated with neurite outgrowth and growth cone motility (Mattson et al., 1988; Rehder and Kater, 1992; Kater et al., 1994). Differentiating amphibian spinal neurons generate waves, spikes, and clusters of $\left[\mathrm{Ca}^{2+}\right]_{\mathrm{i}}$ increase (Spitzer and $\mathrm{Gu}, 1997$ ). Calcium spikes promote normal neurotransmitter expression and channel maturation, whereas $\mathrm{Ca}^{2+}$ waves are associated with neurite extension $(\mathrm{Gu}$ and Spitzer, 1995). The observations presented here of spontaneous $\left[\mathrm{Ca}^{2+}\right]_{\mathrm{i}}$ increases in both proliferative and postmitotic cortical cells suggest that similar changes in $\left[\mathrm{Ca}^{2+}\right]_{\mathrm{i}}$ may underlie different signaling events during distinct phases of neocortical development.

\section{REFERENCES}

Adams RJ (1996) Metaphase spindles rotate in the neuroepithelium of rat cerebral cortex. J Neurosci 16:7610-7618.

Anderson SA, Eisenstat DD, Shi L, Rubenstein J (1997) Interneuron migration from basal forebrain to neocortex: dependence on dlx genes. Science 278:474-476.

Bayer SA, Altman J (1991) Neocortical development. New York: Raven.

Bayer SA, Altman J (1995) Neurogenesis and neuronal migration. In: The rat nervous system (Paxinos G, ed), pp 1070-1078. San Diego: Academic.

Behar TN, Li Y, Tran HT, Ma W, Dunlap V, Scott C, Barker JL (1996) GABA stimulates chemotaxis and chemokinesis of embryonic cortical neurons via calcium-dependent mechanisms. J Neurosci 16:1808-1818.

Berry M, Rogers AW (1965) The migration of neuroblasts in the developing cerebral cortex. J Anat 99:691-709.

Bittman K, Owens DF, Kriegstein AR, LoTurco JJ (1997) Cell coupling and uncoupling in the ventricular zone of developing neocortex. J Neurosci 17:7037-7044.

Blanton MG, LoTurco JJ, Kriegstein AR (1989) Whole cell recording from neurons in slices of reptilian and mammalian cerebral cortex. J Neurosci Methods 30:203-210.

Bohner AP, Akers RM, McConnell SK (1997) Induction of deep layer cortical neurons in vitro. Development 124:915-923.

Boulder Committee (1970) Embryonic vertebrate central nervous system: revised terminology. Anat Rec 166:257-261.

Cai L, Hayes NL, Nowakowski RS (1997) Synchrony of clonal cell proliferation and contiguity of clonally related cells: production of mosaicism in the ventricular zone of developing mouse neocortex. J Neurosci 17:2088-2100.

Caviness Jr V, Takahashi T, Nowakowski RS (1995) Numbers, time and neocortical neuronogenesis: a general developmental and evolutionary model. Trends Neurosci 18:379-383.

Chenn A, McConnell SK (1995) Cleavage orientation and the asymmetric inheritance of Notch1 immunoreactivity in mammalian neurogenesis. Cell 82:631-641.

Cornell-Bell AH, Finkbeiner SM (1991) Ca2+ waves in astrocytes. Cell Calcium 12:185-204.

Feller MB, Wellis DP, Stellwagen D, Werblin FS, Shatz CJ (1996) Requirement for cholinergic synaptic transmission in the propagation of spontaneous retinal waves. Science 272:1182-1187.

Ferrari MB, Rohrbough J, Spitzer NC (1996) Spontaneous calcium transients regulate myofibrillogenesis in embryonic Xenopus myocytes. Dev Biol 178:484-497.

Frantz GD, McConnell SK (1996) Restriction of late cerebral cortical progenitors to an upper-layer fate. Neuron 17:55-61.
Ghosh A, Greenberg ME (1995) Distinct roles for bFGF and NT-3 in the regulation of cortical neurogenesis. Neuron 15:89-103.

$\mathrm{Gu}$ X, Spitzer NC (1995) Distinct aspects of neuronal differentiation encoded by frequency of spontaneous $\mathrm{Ca} 2+$ transients. Nature 375:784-787.

Gu X, Olson EC, Spitzer NC (1994) Spontaneous neuronal calcium spikes and waves during early differentiation. J Neurosci 14:6325-6335.

Guthrie SC, Gilula NB (1989) Gap junctional communication and development. Trends Neurosci 12:12-16.

Kandler K, Katz LC (1995) Neuronal coupling and uncoupling in the developing nervous system. Curr Opin Neurobiol 5:98-105.

Kao JP, Alderton JM, Tsien RY, Steinhardt RA (1990) Active involvement of $\mathrm{Ca} 2+$ in mitotic progression of Swiss $3 \mathrm{~T} 3$ fibroblasts. J Cell Biol 111:183-196.

Kater SB, Davenport RW, Guthrie PB (1994) Filopodia as detectors of environmental cues: signal integration through changes in growth cone calcium levels. Prog Brain Res 102:49-60.

Katz LC, Shatz CJ (1996) Synaptic activity and the construction of cortical circuits. Science 274:1133-1138.

Keith CH, Ratan R, Maxfield FR, Bajer A, Shelanski ML (1985) Local cytoplasmic calcium gradients in living mitotic cells. Nature 316:848-850.

Kim GJ, Shatz CJ, McConnell SK (1991) Morphology of pioneer and follower growth cones in the developing cerebral cortex. J Neurobiol 22:629-642.

Komuro H, Rakic P (1992) Selective role of N-type calcium channels in neuronal migration. Science 257:806-809.

Komuro H, Rakic P (1996) Intracellular Ca2+ fluctuations modulate the rate of neuronal migration. Neuron 17:275-285.

Lee MK, Tuttle JB, Rebhun LI, Cleveland DW, Frankfurter A (1990) The expression and posttranslational modification of a neuron-specific beta-tubulin isotype during chick embryogenesis. Cell Motil Cytoskeleton 17:118-132.

LoTurco JJ, Kriegstein AR (1991) Clusters of coupled neuroblasts in embryonic neocortex. Science 252:563-566.

LoTurco JJ, Owens DF, Heath MJS, Davis MBE, Kriegstein AR (1995) GABA and glutamate depolarize cortical progenitor cells and inhibit DNA synthesis. Neuron 15:1287-1298.

Lu KP, Means AR (1993) Regulation of the cell cycle by calcium and calmodulin. Endocr Rev 14:40-58.

Lu N, DiCicco-Bloom E (1997) Pituitary adenylate cyclase-activating polypeptide is an autocrine inhibitor of mitosis in cultured cortical precursor cells. Proc Natl Acad Sci USA 94:3357-3362.

Mattson MP, Taylor-Hunter A, Kater SB (1988) Neurite outgrowth in individual neurons of a neuronal population is differentially regulated by calcium and cyclic AMP. J Neurosci 8:1704-1711.

McConnell SK (1995) Constructing the cerebral cortex: neurogenesis and fate determination. Neuron 15:761-768.

McConnell SK, Kaznowski CE (1991) Cell cycle dependence of laminar determination in developing neocortex. Science 254:282-285.

McConnell SK, Ghosh A, Shatz CJ (1994) Subplate pioneers and the formation of descending connections from cerebral cortex. J Neurosci 14:1892-1907.

Menezes JR, Luskin MB (1994) Expression of neuron-specific tubulin defines a novel population in the proliferative layers of the developing telencephalon. J Neurosci 14:5399-5416.

Meyer T (1991) Cell signaling by second messenger waves. Cell 64:675-678.

Murray A, Hunt T (1993) The cell cycle: an introduction. New York: Freeman.

Newman EA, Zahs KR (1997) Calcium waves in retinal glial cells. Science 275:844-847.

O'Rourke NA, Chenn A, McConnell SK (1997) Postmitotic neurons migrate tangentially in the cortical ventricular zone. Development 124:997-1005.

Owens DF, Boyce LH, Davis MBE, Kriegstein AR (1996) Excitatory GABA responses in embryonic and neonatal cortical slices demonstrated by gramicidin perforated patch recordings and calcium imaging. J Neurosci 16:6414-6423.

Peinado A, Yuste R, Katz LC (1993a) Extensive dye coupling between rat neocortical neurons during the period of circuit formation. Neuron 10:103-114.

Peinado A, Yuste R, Katz LC (1993b) Gap junctional communication and the development of local circuits in neocortex. Cereb Cortex 3:488-498. 
Pende M, Fisher TL, Simpson PB, Russell JT, Blenis J, Gallo V (1997) Neurotransmitter- and growth factor-induced cAMP response element binding protein phosphorylation in glial cell progenitors: role of calcium ions, protein kinase $\mathrm{C}$, and mitogen-activated protein kinase/ ribosomal S6 kinase pathway. J Neurosci 17:1291-1301.

Poenie M, Alderton J, Tsien RY, Steinhardt RA (1985) Changes of free calcium levels with stages of the cell division cycle. Nature 315:147-149.

Rakic P (1995) Radial glial cells: scaffolding for brain construction. In: Neuroglia (Kettenmann H, Ransom BR, eds), pp 746-762. Oxford: Oxford UP.

Ratan RR, Maxfield FR, Shelanski ML (1988) Long-lasting and rapid calcium changes during mitosis. J Cell Biol 107:993-999.

Reddy GP (1994) Cell cycle: regulatory events in G1->S transition of mammalian cells. J Cell Biochem 54:379-386.

Rehder V, Kater SB (1992) Regulation of neuronal growth cone filopodia by intracellular calcium. J Neurosci 12:3175-3186.

Reznikov K, van der Kooy D (1995) Variability and partial synchrony of the cell cycle in the germinal zone of the early embryonic cerebral cortex. J Comp Neurol 360:536-554.

Seymour RM, Berry M (1975) Scanning and transmission electron microscope studies of interkinetic nuclear migration in the cerebral vesicles of the rat. J Comp Neurol 160:105-125.

Spitzer NC, Gu X (1997) Purposeful patterns of spontaneous calcium transients in embryonic spinal neurons. Semin Cell Dev Biol 8:13-19.

Spray DC, Harris AL, Bennett MV (1981) Comparison of $\mathrm{pH}$ and calcium dependence of gap junctional conductance. Kroc Foundation Series 15:445-461.
Takahashi T, Nowakowski RS, Caviness Jr V (1995) The cell cycle of the pseudostratified ventricular epithelium of the embryonic murine cerebral wall. J Neurosci 15:6046-6057.

Thastrup O, Cullen PJ, Drobak BK, Hanley MR, Dawson AP (1990) Thapsigargin, a tumor promoter, discharges intracellular $\mathrm{Ca} 2+$ stores by specific inhibition of the endoplasmic reticulum $\mathrm{Ca} 2(+)$-ATPase. Proc Natl Acad Sci USA 87:2466-2470.

Turin L, Warner A (1977) Carbon dioxide reversibly abolishes ionic communication between cells of early amphibian embryo. Nature 270:56-57.

Ullrich A, Schlessinger J (1990) Signal transduction by receptors with tyrosine kinase activity. Cell 61:203-212.

Whitfield JF, Bird RP, Chakravarthy BR, Isaacs RJ, Morley P (1995) Calcium-cell cycle regulator, differentiator, killer, chemopreventor, and maybe, tumor promoter. J Cell Biochem [Suppl] 22:74-91.

Wong RO, Chernjavsky A, Smith SJ, Shatz CJ (1995) Early functional neural networks in the developing retina. Nature 374:716-718.

Yuste R (1997) Introduction: spontaneous activity in the developing central nervous system. Semin Cell Dev Biol 8:1-4.

Yuste R, Katz LC (1991) Control of postsynaptic $\mathrm{Ca}^{2+}$ influx in developing neocortex by excitatory and inhibitory neurotransmitters. Neuron 6:333-344.

Yuste R, Peinado A, Katz LC (1992) Neuronal domains in developing neocortex. Science 257:665-669.

Yuste R, Nelson DA, Rubin WW, Katz LC (1995) Neuronal domains in developing neocortex: mechanisms of coactivation. Neuron 14:7-17. 